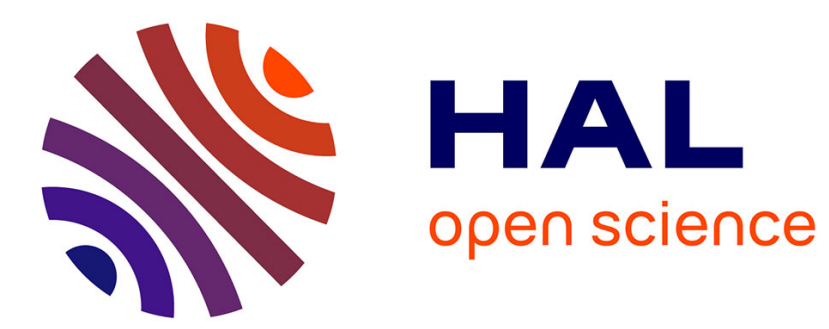

\title{
Diet and ecology of prosimians
}

Claude Marcel Hladik

\section{To cite this version:}

Claude Marcel Hladik. Diet and ecology of prosimians. G.A. DOYLE \& R.D. MARTIN. The study of prosimian behavior, Academic Press, New York, pp.307-357, 1979. hal-00561750

\section{HAL Id: hal-00561750 https://hal.science/hal-00561750}

Submitted on 13 Mar 2013

HAL is a multi-disciplinary open access archive for the deposit and dissemination of scientific research documents, whether they are published or not. The documents may come from teaching and research institutions in France or abroad, or from public or private research centers.
L'archive ouverte pluridisciplinaire HAL, est destinée au dépôt et à la diffusion de documents scientifiques de niveau recherche, publiés ou non, émanant des établissements d'enseignement et de recherche français ou étrangers, des laboratoires publics ou privés. 
HLADIK C.M. (1979) — Diet and ecology of prosimians. In : G.A. DOYLE \& R.D. MARTIN (Eds.) The study of prosimian behavior. Academic Press, New York : 307-357.

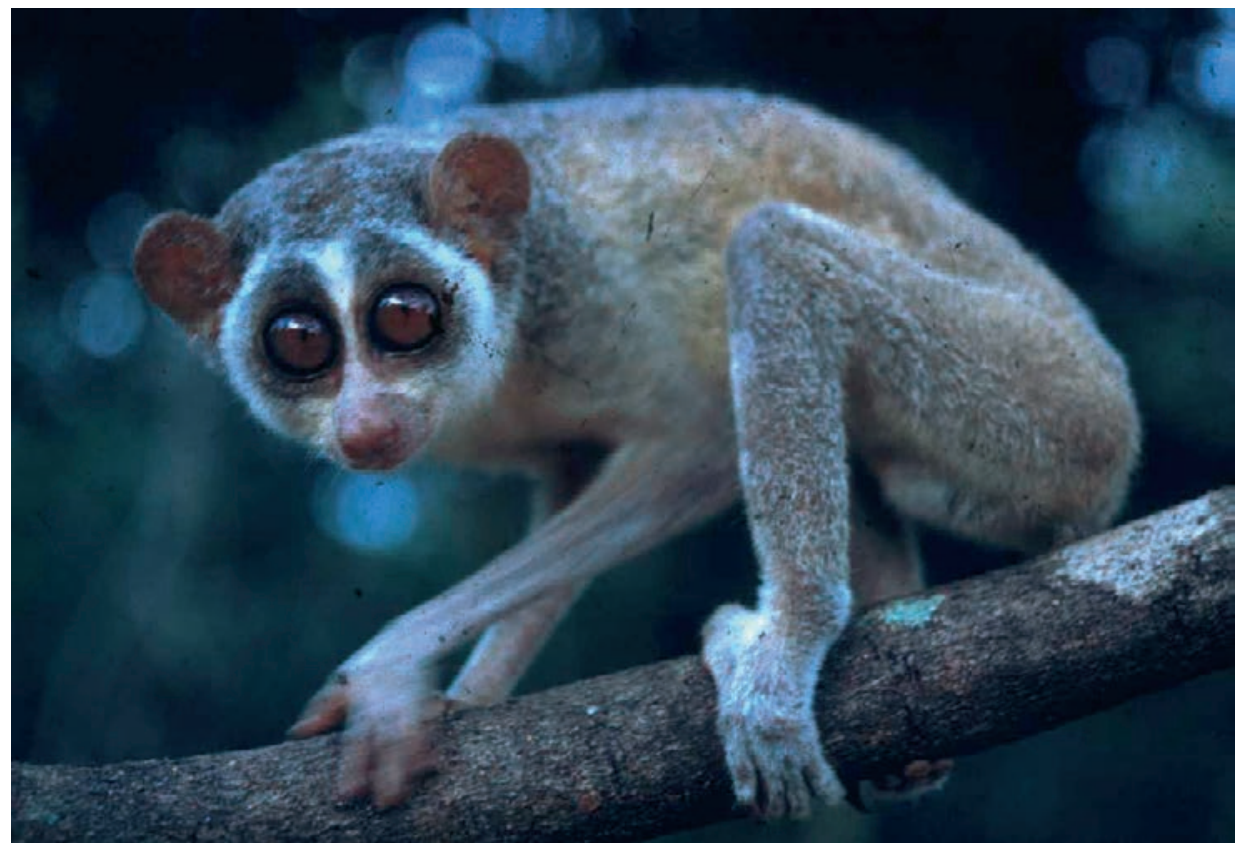

Loris tardigradus during the field study in the dry forest of Sri Lanka (photo C.M. Hladik)

Address in 2013: Claude Marcel HLADIK

Directeur de recherche émérite

Eco-Anthropologie et Ethnobiologie

Muséum National d'Histoire Naturelle

4 avenue du Petit Château

91800 Brunoy (France)

cmhladik@mnhn.fr

<http://www.ecoanthropologie.cnrs.fr/IMG/pdf_Site-WEB-Hladik-2013.pdf>

\section{Diet and Ecology of Prosimians}

\author{
C. M. HLADIK
}

1. Definition of Diet in Relation to Field and Laboratory Research Methods .... 307 1.1. What Is the Diet of a Primate Species? ..................... 307

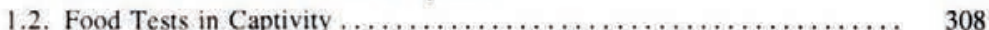

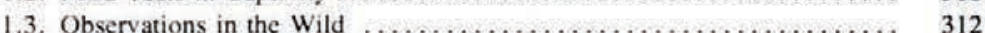

1.4. Methods of Collecting and Processing Food Samples ................. 314

2. Ecology and Specialization in the Diet of Prosimians ................ 316

2.1. Dietary Specializations in Relation to Morphology ................ 316

2.2. Specialization in Relation to Ecological Niche .........................

24. Noctumal Prosimians of Madagascar .

2.5. Diurnal Prosimians of Madagascar $\ldots \ldots \ldots \ldots \ldots \ldots \ldots \ldots \ldots . \ldots \ldots, 340$

3. Social Life in Relation to Diet and Ecology ......................... 342

3.1. Home Range, Territory, and the "Supplying Area" ............. 342

3.2. Social Patterning in Relation to Habitat Utilization .................. 344

3.3. Food Traditions and Learning .

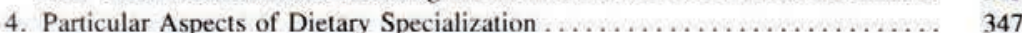

4.1. Flexibility in Different Types of Diets .......................... 347

4.2. Cecotrophy in Lepilemur ................................ 349

4.3. Artifical Diets: the G3 Lemur Cake of Brunoy ................... 35

5. Food Composition and Feeding Behavior of Prosimians ................ 352

5.1. Regulation of Feeding Behavior ...................... 352

5.2. Food Conditioning under Natural Conditions ................. 352

6. Discussion and Conclusions ............................. 353

References .................................... 355

\section{DEFINITION OF DIET IN RELATION TO FIELD AND}

LABORATORY RESEARCH METHODS

\subsection{What Is the Diet of a Primate Species?}

This question usually elicits immediate and obvious answers with reference to certain types of animals: herbivores eat only grass or leaves while carnivores look 
for live prey. Although we intuitively refer to a "standard eating behavior" it is never as clear-cut for most prosimians and other primate species. Feeding behavior is a selective response to stimulation (Hinde, 1966), but no overall explanation for the specific food choices of closely related species has ever been proposed. Hypotheses will be presented at the conclusion of this chapter but, to formulate a clear definition of diet, we must refer to qualitative as well as quantitative data. The methods used (tests and different types of observations) yield different types of information, the value of which will be discussed.

\subsection{Food Tests in Captivity}

The simplest method of investigating dietary preferences consists in presenting various types of food to a caged animal and recording what it selects and what it rejects. A quantitative estimate of food preferences can be obtained for each type of food from the difference in weight between the food offered and what remains. Petter (1962) used some of these tests to supplement information on the natural diet in his first overall survey of the Malagasy lemurs.

Charles-Dominique (Charles-Dominique and Bearder, Chapter 13) demonstrated that such tests did not entirely support the results of his own field observations of the natural diet of different prosimian species. Fruits and different species of insects were given ad libitum, to five different lorisid species in captivity that had already been intensively studied in the wild. All five species ate large amounts of insects (mainly Orthoptera) for several months, although their natural diet includes smaller amounts of insects with differences between the species in "preferential" food choices. In three of them, Perodicticus potto, Galago elegantulus (Euoticus elegantulus), and $G$. alleni, insects make up only $10-25 \%$ of the natural diet and there are marked differences in choice of insects, especially between the two other species, G. demidovii and Arctocebus calabarensis, the latter feeding mainly on caterpillars and insects avoided by the other species (see Section 2.3 below).

Food preferences in natural conditions are thus determined not only by the availability of insects but also by the ability of the species concerned to locate and catch them. For example, Arctocebus calabarensis prefer locusts and crickets in captivity but, under natural conditions, they feed on insects avoided by the other species and which, according to our analysis, are of less nutritional value, simply because they are not able to find and catch more edible prey.

Laboratory tests can be used to determine the types of prey that continue to be rejected when nothing else is available. A recent experimental study by $G$. Bernardi and P. Charles-Dominique (personal communication) was conducted on the five nocturnal lorisids mentioned above, using as prey a number of butterflies and moths available in their natural habitat in the rain forest of Gabon. Most edible Lepidoptera are cryptic and are eaten by all lorisid species while many moth species, which are also edible, have ocellated lower wings (containing eyelike spots) that might frighten predators. The less edible Lepidoptera are noncryptic and may display brightly colored wings signaling their unpalatibility to potential predators. Some of these may be eaten by Perodicticus potto and Arctocebus calabarensis, but the various Galago species, once having tasted them, never again try to eat them. Taste, which is certainly not identical in the different prosimian species, results in Perodicticus and Arctocebus having a wider choice of the less edible prey, allowing them to utilize those that are generally available in large quantities since they are avoided by the other insectivorous species. The mechanism of food selection in Loris (see below) is very similar.

Food tests using a larger sample of potential prey were conducted as part of our field study on Loris tardigradus (Fig. 1) in Sri Lanka (Petter and Hladik, 1970). The results obtained (Table I) were in agreement with previous experiments of Still (1905) and Philips (1931). They showed that Loris may feed on types of invertebrates that are neglected by the other predators (birds and monkeys) living in the same area. For instance the Reduvidae, a type of Homoptera with bright bronzegreen wings, which obviously act as a deterrent signal to potential predators, as well as the most common butterfly, Euploea core (neglected by the insectivorous birds),

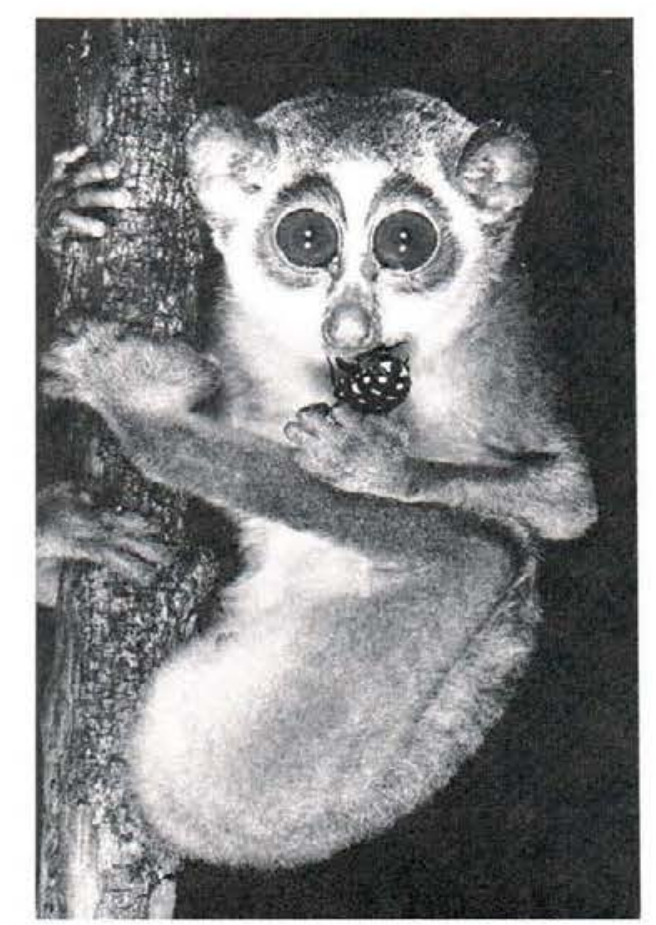

Fig. 1. Loris tardigradus feeding on a Coleoptera Cetoniidac, which is rejected by other insectivorous species. during food tests of potential prey in the dry deciduous forest of Sri Lanka. (Photograph: C. M. Hladik.) 
TABLE I

Results of Food-Choice Tests on Loris tardigradus ${ }^{a, b}$

\begin{tabular}{|c|c|}
\hline Food choice & Prey \\
\hline+ & Molluses (snails) \\
\hline - & Annelidae (earthworms) \\
\hline \multirow[t]{2}{*}{ - } & Myriapods (Iulidae and other types) \\
\hline & Arachnids \\
\hline++ & Salticidae \\
\hline \multirow[t]{2}{*}{++} & Opilionidae \\
\hline & Insects \\
\hline \multirow[t]{2}{*}{+} & Hemiptera (Reduvidae) \\
\hline & Orthoptera \\
\hline++ & Forficula \\
\hline \multirow{2}{*}{++} & Grasshopper and crickets \\
\hline & Coleoptera \\
\hline++ & Cerambycidac \\
\hline++ & Curculionidae \\
\hline+ & Cetoniidae \\
\hline - & Carabidae \\
\hline++ & Lepidoptera (imago of Sphyngidae and caterpillars) \\
\hline++ & Other moths \\
\hline+ & Euploea core (Danaidae) \\
\hline - & Unidentified caterpillars with long hair \\
\hline++ & Hymenoptera (ants) \\
\hline \multirow[t]{2}{*}{++} & Diptera (flies) \\
\hline & Vertebrates \\
\hline - & frogs \\
\hline+ & geckoes \\
\hline
\end{tabular}

were eaten, albeit reluctantly, by $L$. tardigradus. These tests demonstrate to what extent Loris may utilize the least edible types of prey, without proving what is actually eaten by preference in the wild. Nevertheless, the results partly explain the mechanism of specialization in feeding behavior, very similar in Arctocebus calabarensis and Loris tardigradus.

Positive results from tests on food choices have recently been obtained after a 2 -year study conducted in our animal house at Brunoy (Petter-Rousseaux and Hladik, in press). Free access to food was given to five species of nocturnal prosimians which normally live sympatrically in the forest of the western coast of Madagascar-Cheirogaleus medius, Microcebus murinus, $M$. coquereli, Phaner furcifer, and Lepilemur ruficaudatus. A common set of various foods was placed in each of the cages containing one or several animals of the same species. The weights of the different foodstuffs ingested were calculated, after taking into account loss of weight by evaporation determined by means of food samples left outside the cages. The main purpose of this experiment was to collect data on the different physiological cycles, but the results concerning preferential food choices, some of which are presented in Table II, give evidence of important differences between the prosimian species, that can be related to their diets under natural conditions (see Section 2.4 below). Among these five species, $C$. medius are the most frugivorous, $M$. murinus the most insectivorous, and $L$. ruficaudatus the most folivorous.

King (1974), using the same type of food tests, found a slight difference between the diets of Lemur macaco and $L$. mongoz which might reflect slight differences under natural conditions.

In conclusion, food tests in captivity do not yield precise information about natural diet. At best they may help to explain some mechanisms of food selection when testing with prey and other food types occurring in the environment of a prosimian species. The tests on artificial diets, such as those presented in Table II, give evidence of differences between species, independent of social tradition, since the food samples utilized never occur in the wild. These differences are related to the way species perceive food as well as to more complex physiological adaptations (see discussion on "flexibility" in Section 4.1 below) that determine the different possible expressions of feeding behavior.

\section{TABLE II}

Relative Proportions of the Fresh Weight of Different Food Categories Ingested in One Year by Five Species of Sympatric Nocturnal Prosimian ${ }^{a . t}$

\begin{tabular}{cccccc}
\hline & $\begin{array}{c}\text { Microcebus } \\
\text { coquereli } \\
(\%)\end{array}$ & $\begin{array}{c}\text { Phaner } \\
\text { furcifer } \\
(\%)\end{array}$ & $\begin{array}{c}\text { Cheirogaleus } \\
\text { medius } \\
(\%)\end{array}$ & $\begin{array}{c}\text { Microcebus } \\
\text { murinus } \\
(\%)\end{array}$ & $\begin{array}{c}\text { Lepilemur } \\
\text { ruficaudatus } \\
(\%)\end{array}$ \\
\hline $\begin{array}{c}\text { Leaves of lettuce } \\
\text { and willow tree }\end{array}$ & 0 & 0 & 0 & 0 & 39.9 \\
$\begin{array}{c}\text { Pulp of apples } \\
\text { and pears }\end{array}$ & 22.2 & 15.7 & 4.9 & 2.5 & 38.3 \\
$\quad \begin{array}{c}\text { Cucumber and } \\
\text { other fruits }\end{array}$ & 1.2 & 1.2 & 1.9 & 2.9 & 1.1 \\
$\begin{array}{c}\text { Banana } \\
\text { Mixture of milk }\end{array}$ & 42.8 & 40.0 & 76.9 & 48.2 & 0.2 \\
$\quad$ and flour & 11.6 & 15.7 & 7.6 & 12.3 & 7.2 \\
$\begin{array}{c}\text { G3 Lemur cake } \\
\quad \text { protein and fat) }\end{array}$ & 21.5 & 26.5 & 8.6 & 31.4 & 12.9 \\
Meat and insects & 0.7 & 0.9 & 0.1 & 2.7 & 0.4 \\
\hline
\end{tabular}

"After Petter-Rousseaux and Hladik (in press).

"Except for insects, the different types of food were available ad lihitum. 


\subsection{Observations in the Wild}

In the last 15 years more observations have been carried out on wild primates than during the entire preceding period of scientific research. Observations on wild prosimians were even more recently intensified (cf. Doyle and Martin, 1974). However, it seems that feeding behavior has been relatively neglected compared to other aspects of the socioecology of prosimians, the reason being that quantitative observations on feeding behavior are generally very difficult to carry out in the natural habitat, and indirect methods have to be used to study both diurnal and nocturnal prosimian species.

\subsubsection{Studies of the Diet of Diurnal Prosimians}

It is surprising that the simple method of direct visual recording has seldom been used in quantitative studies to describe the diet of diurnal species of prosimians living in the dry deciduous forest where conditions of visibility are good. A fairly accurate estimate of the natural diet can be achieved by following one target animal for an entire day and counting the number of different fruits and leaves actually eaten, after which samples of each type of food can be collected to allow for calculation of the average weight of material ingested by the animal. This method has been used on different species of primate by the author (Hladik and Hladik, 1969, 1972; Hladik, 1973, 1975) and by Iwamoto (1974a, b). Comparison of the diets of the different species cannot be made on the basis of a list of Latin names, even if the proportions of food eaten are known. A further analysis of the food samples collected (Hladik et al., 1971a; Hladik, 1977b) is necessary to allow for calculation of the average composition of the diets permitting interspecific comparisons. Such results can be related to specific physiological characteristics subject to further investigation by the methods described in the preceding section.

In most recent studies of wild diurnal prosimians, time has been used as a measure of feeding behavior. The time a target animal spent feeding on different food items was directly recorded by Richard (1973), while Sussman (1972) obtained an indirect measure of this time by periodical observation of individual activity records. But feeding time is not diet and, accordingly, Sussman and Richard (1974) used their measures essentially to compare the time budgets and behavior of different species. A detailed discussion of the correlation between feeding time and diet (Hladik, 1977a) reveals that comparison of the diets of frugivorous species is essentially meaningless when based on feeding times, while for species feeding on leaves and other common foods of homogeneous structure the correlation is more accurate. The above-mentioned studies, as well as the descriptions of Jolly (1966) comparing feeding data of lemur species living on the same common resources, go a long way toward presenting an accurate picture of the diet itself.

The density of wild vegetation is the main obstacle to direct observation, and continuous recording of the feeding behavior of one target animal is particularly difficult in the rain forest. For this reason one is unlikely to obtain data on the diet of
Indri indri, for instance, that are more detailed than those of Pollock $(1975,1977)$ who made 3000 regular observations and attempted to complement his quantitative data by the analysis of fecal material. Since many of the diurnal prosimians of Madagascar are endangered species data cannot be collected by sacrificing animals. By contrast, in exceptional areas where conditions of visibility are good, such as the deciduous forest of the south of Madagascar, quantitative studies of diet based on direct observation of the less shy lemur species would be a highly valuable complement to the work of Jolly (1966), Sussman (1972, 1974), Richard (1973, 1974), and Budnitz and Dainis (1975). If, in addition, chemical analysis of food samples eaten over a yearly cycle were to be undertaken, the results would provide a basis for further physiological investigations.

\subsubsection{Studies of the Diet of Nocturnal Prosimians}

Direct observation at night requires rather exceptional conditions if the same order of accuracy is to be achieved as observations during the day. The unique conditions of visibility found in the "bush" of the south of Madagascar at night, during the dry season, constitute such conditions of obtaining direct quantitative information on the diet of Lepilemur leucopus (Charles-Dominique and Hladik, 1971). During this study, the feeding rates of captive $L$. leucopus were first controlled from a short distance, using plant species normally eaten in the wild. When the animals were browsing, the rate of ingestion was shown to be very constant. The information thus gained permitted accuracy in subsequent field measurements.

Indirect measures of food ingested necessitate trapping or shooting of animals. For species that are not subject to total protection, such as the prosimians of continental Africa, the collection of stomach contents gives very important results. Charles-Dominique (1966, 1971 a, 1974a; Charles-Dominique and Bearder, Chapter 13) worked in a large area of primary forest located within a radius of $40 \mathrm{~km}$ around Makokou (Gabon), where prosimians are not hunted by local people because of the availability of larger game. The total of 174 specimens collected in three years in this area represents a very small fraction of the prosimian population (estimated at less than 1/1000). Thus this method, when correctly applied in a large area, can have no adverse effects on conservation of the species.

Analysis of the different proportions of the stomach contents is generally limited to an overall description of gross classes of foodstuff (leaves, fruits, insects, etc.). Invertebrate prey can be identified more accurately from the chitinous remains. By contrast, the pulp of many fruits, when the pit has not been swallowed, does not generally retain any obvious specific characteristics sufficient to allow for identification. Juicy parts, that might be very important in the diet, are totally omitted in this kind of description which is, nevertheless, the main source of information on the diet when direct observation is not possible.

The entire digestive tract of the sacrificed animal must be carefully examined, in addition to the stomach contents, since it may retain seeds and any other solid matter giving additional information about the food ingested. A very good example of the 
need for this careful approach is given by Charles-Dominique (1971a, 1974a), In the stomach contents of Galago elegantulus and Perodicticus potto there is generally no trace of the gums eaten by these animals on trees and lianas. Gums may, however, be found in the cecum (particularly in $G$. elegantulus). It seems that gums are retained in the stomach only for a few minutes while other foods (fruits and insects) stay longer. Thus, in these particular cases, the diet was calculated from the weight of the cecum content added to the weight of the stomach content

In Madagascar, where all the nocturnal prosimian species are fully protected. quantitative information on diet is currently being compared by the analysis of feces (Hladik et al., in press). During a field study carried out on the west coast (Petter, 1978), all the nocturnal prosimians were trapped for marking and prepared for radio tracking. Before release, the first feces of the animals were collected (other feces would contain the fruits used as baits). The remains identified in the feces represent only a part of what was actually ingested, even smaller than the part identified in the stomach itself. As an example, the diet of Microcebus coquereli includes large amounts of the sweet liquid secretion of Homoptera (see Section 2.4 below) that would have been undetected without direct observation.

Data from field work, which yield information about the "natural diet" of a given species, are not generally very accurate and must be complemented by other methods. Diet is related to environmental factors, thus local variations have to be considered. The composition of the food ingested is the main criterion for interspecific comparison of diet.

\subsection{Methods of Collecting and Processing Food Samples}

Most of the foods utilized by wild primates are unknown. Food samples have, therefore, to be collected and kept in sufficiently good condition for later analysis. Different analytical tests are appropriate for different methods of preservation (Hladik, 1977b). In this respect, a few important points will be presented at the end of this technical section.

The major method of obtaining food samples located on trees is by means of a tree pruner fixed at the end of a long pole. Bamboo is the least fragile material with which to build a pole up to $15 \mathrm{~m}$, made of separate parts bound together with tenons, which allows direct collection from most deciduous trees (cf. Hladik, 1977a). Collection from the higher trees of the evergreen tropical forest calls for a "climbing tree stand." A very safe model of a tree stand (Forestry Suppliers, Inc., Jackson, Mississippi) was used in field work in Gabon to climb as high as $30 \mathrm{~m}$ along smooth tree trunks, without any special training. The samples of leaves and fruits must be collected in large amounts (at least $200 \mathrm{gm}$ wet weight) and kept in plastic bags to prevent loss of water before weighing and processing.

Drying is the most convenient process for preserving food samples in field conditions. This process must be as fast as possible compatible with maximum preservation of specimens (i.e., heat no higher than $60^{\circ}$ to $80^{\circ} \mathrm{C}$ ). Two types of simplified dryers are presented in Fig. 2. Basically they consist of a box of wood or metal, embodying a heat source and designed to allow sufficient air circulation compatible with the maintenance of a fairly high uniform temperature around the box. Botanical specimens, necessary for identification of food samples, can be dried simultaneously. Food samples are kept in nonglossy paper bags on which weight and any other important information is marked. After drying to constant weight, the paper bags with food samples are sealed in plastic bags.

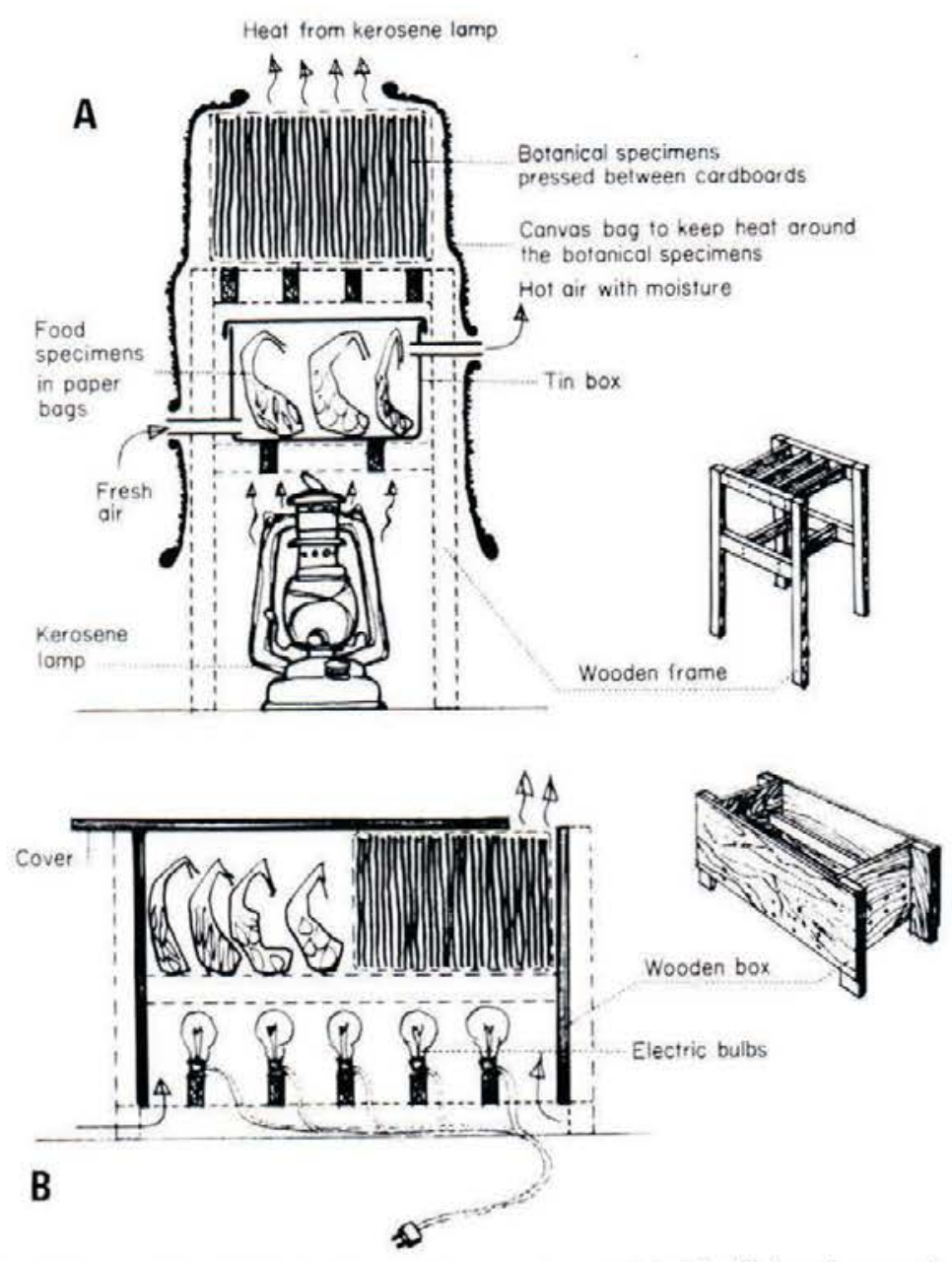

Fig. 2. Models of dryers for preparation of fond samples. (A) Model utilizing a kerosene lamp to dry food specimens and botanical specimens under field conditions. (B) Simplified electric dryer used at the field station. 
Many of the standard operations of analysis (titration of minerals, nitrogen, lipids, total carbohydrate, and cellulose) can be carried out on dried food samples. Further investigations require another type of field processing, such as fixation in ethyl alcohol. Here the sample is sliced in small pieces ( $2 \mathrm{~mm}$ thickness) and maintained for about 10 minutes in boiling ethyl alcohol ( $96^{\circ}$ at alcoholometer) in a flask equipped with a condensor. The samples can be stored in plastic jars with the alcoholic solution. This process is considered one of the best for preventing enzymatic reactions: thus soluble sugars, amino acids, and lipids can be separately titrated. Deep freezing (below $-30^{\circ} \mathrm{C}$ ) would also allow any kind of analysis, but this method is not generally convenient in field conditions.

It is beyond the scope of this chapter to go into greater detail about food sample analysis (see Hladik et al., 1971a; Hladik, 1977b): the main point is that interspecific comparison of diet requires the use of similar methods for investigating the diets of different species.

\section{ECOLOGY AND SPECIALIZATION IN THE DIET OF \\ PROSIMIANS}

\subsection{Dietary Specializations in Relation to Morphology}

Several morphological characteristics have evolved in prosimians as a result of the selective pressures of the limited number and quantity of natural foods available in different habitats. Conversely the acquisition of certain characteristics, such as large body size, has reduced the range of possible adaptations to different diets.

\subsubsection{Diet in Relation to Body Size}

Variability in the composition of the most common substances eaten by primates in the wild (insects, fruits, gums, leaves) is important but restricted to limits within each category, as shown by the examples presented in Table III. The smallest species $(0.1-0.2 \mathrm{~kg})$ utilize insects or other small invertebrate prey as a staple food. Thus their diet, including a maximum amount of protein and fat, yields a maximum of energy (necessary for small mammalian forms, according to basic principles of metabolism). If we consider larger species $(0.2-0.5 \mathrm{~kg})$, the maximum amount of insect food they can obtain is approximately constant in a given habitat, since the chances of finding prey during one day (or one night for nocturnal forms) are fairly similar for different species irrespective of size, as demonstrated by Hladik and Hladik (1969) and by Charles-Dominique (1971a). These species have, therefore, to utilize other food resources, such as gums and fruits, to obtain sufficient energy in carbohydrate; the larger the species, the greater the amount of fruit necessary.

Most prosimians of large size $(0.5-2.0 \mathrm{~kg})$ rely on fruits as their staple food. The amount of insect food they eat is relatively small in relation to their weight, but this animal food is necessary to balance the overall proportion of protein in their diet. As

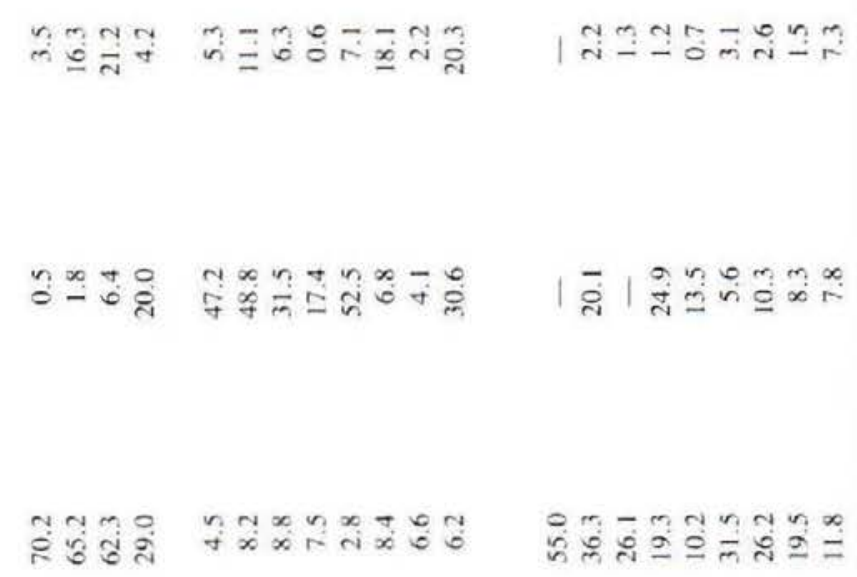

ํำ


a matter of fact, fruits yield an average of $5 \%$ protein (by dry weight) which is not sufficient to compensate for nitrogen loss. For the largest species $(3-10 \mathrm{~kg})$, even the protein that could be obtained from insects would not compensate for fruit protein deficiency. The diet of these large forms must include leaves or other green vegetable matter, a ubiquitous resource rich in protein. Leaf buds and young leaves are preferentially eaten because they yield more protein (25-35\% by dry weight, with a maximum of $55 \%$ observed in the shoots of leguminous trees, Hladik, 1978). Thus the largest prosimian species are generally frugivorous and folivorous.

Some of these large prosimians, such as Indri indri, utilize leaves as a staple food (Pollock, 1977) and fruits might be regarded simply as supplementing the carbohydrate in their diet. For such folivorous animals, insects would no longer be necessary as a protein supplement since foraging for insects would yield too small an amount of protein in relation to body size and energy expenditure.

\subsubsection{The Prosimian Hand and Its Ability to Manipulate Food Objects}

The above statement does not apply to diurnal lemur species weighing between 2 and $4 \mathrm{~kg}$. These species feed mainly on fruits and leaves (see Section 2.5 below) and it may well be asked why they do not eat insects, at least in small amounts, when this food resource is readily available. In fact, the relation between diet and body size presented above for prosimians also applies to the smaller simian primates (Hladik, 1975, 1978) and among these the forest-dwelling monkeys, weighing 2-4 $\mathrm{kg}$, have a diet which includes insects as well as leaves, to supplement the low protein content of fruits. The foraging techniques of monkeys (Thorington, 1967; Hladik and Hladik, 1969, 1972; Gautier-Hion, 1971) involve a very sophisticated hand allowing complex manipulation of bark and dead leaves to find the insects and other invertebrate prey in sufficient quantity.

The parallel evolution of vision is also very important for an efficient foraging technique (see Pariente, 1976, and Chapter 10).

The prosimian hand, with its fairly fixed pattern of control (all fingers press the object toward the distal or proximal palmar pads; Bishop, 1964) does not allow such complex manipulations. Consequently prosimians have not been able to develop the foraging techniques of the simians and the feeding strategy involving leaf-eating, as a supplement to frugivorous diets, has been adopted by species of relatively small size. As suggested by Charles-Dominique (1975, 1977a), the evolution of the prosimian hand may well have stopped at an early stage in evolution because it was already highly specialized for stereotyped movements. These stereotyped movements, perfectly adapted to catch small insects moving rapidly or in flight, are used by small, primitive insectivorous forms (Fig. 3A and B) but, in larger lemur species (Fig. 3C), manipulation of food objects is limited to a hooklike gesture. In spite of a slight difference in the arrangement of the digits when they grasp a piece of food, the Lemuridae, if artificially trained to eat insects, are also able to perform a stereotyped movement resembling that of the small insectivorous species of
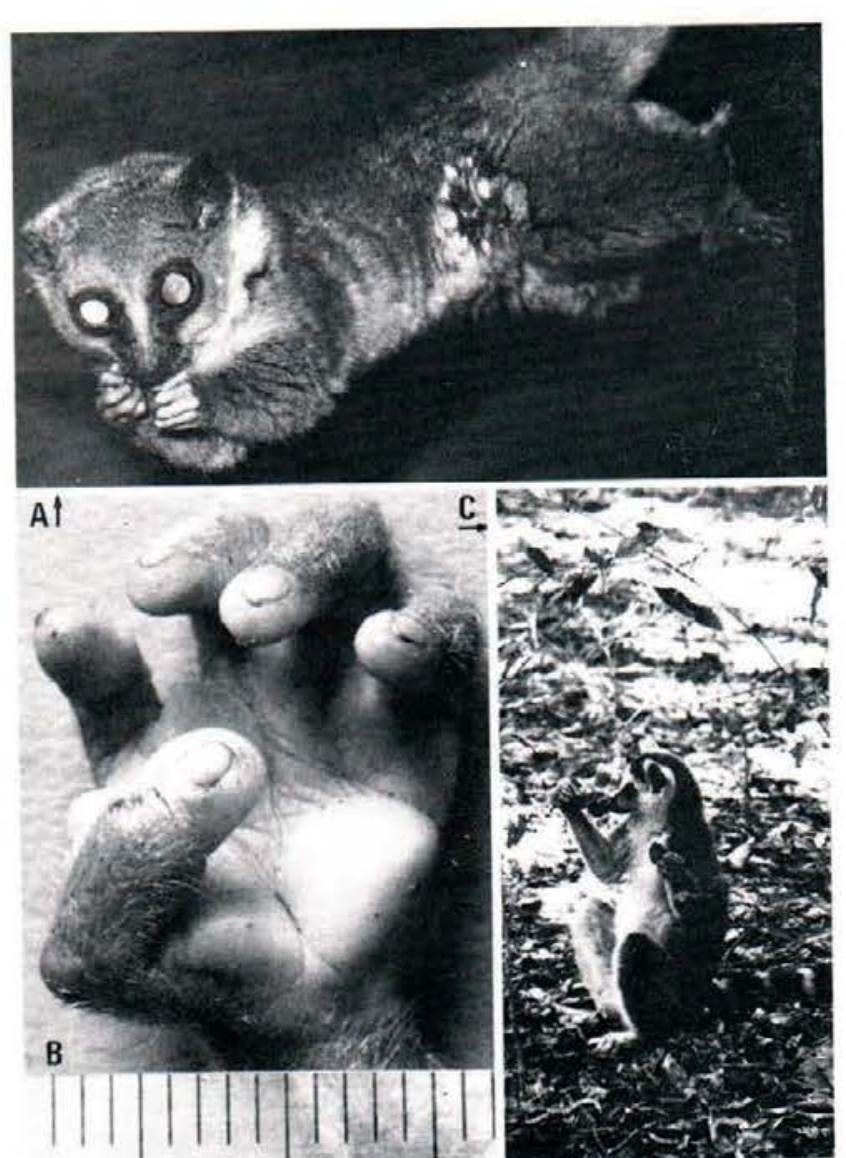

Fig. 3. Movements of prosimian hands while feeding. (A) Microcebus murinus catching an insec with a stereotyped movement of both hands-all fingers converge simultaneously as soon as the dista palmar pad touches the prey. Note the particular position of the body-hanging by the legs only. (Photogarar the convergent graph: R. D. Main position of all fingers. The scale is in millimeters. (Photograph: the proximal palmar pad. (Photograph: A. Schilling.)

Lorisid. This type of movement has been observed in Lemur fulvus and L. mongoz (Charles-Dominique, 1975).

\subsubsection{Prosimian Teeth and the Digestive Tract}

A recent general study of primate dentition compared to that of other mammals (Kay and Hylander, 1978) illustrates the difference in function between the front teeth and the cheek teeth. Incisors, canines, and premolars are used for seizing, 
manipulating, and separating food while biting it; the essential function of the molar teeth, on the other hand, is mastication. Species that eat food that needs to be shredded during mastication require large shearing blades on their molars and, depending on the molar structure in different taxonomic groups, different cusps might be developed for this purpose. Consequently the rear part of the mandible of the folivorous species must be large. By contrast, the extension of the front part of the mandible is an adaptation to frugivorous/insectivorous diets.

A peculiar dental structure is found in the lorisids as well as in the Malagasy lemurs (though not restricted to them, if considering converging forms in other mammals): the two canines and four incisors of the lower jaw, are styliform and almost horizontal, forming a "tooth-scraper. " This instrument is frequently called a "dental comb" (Buettner-Janusch and Andrew, 1962) because of its frequent use by prosimians in grooming. The term "tooth-scraper" (Martin, 1972b) probably better reflects its functional adaptation in the extant species, and particularly among those feeding on large amounts of gums and/or sap, such as Galago elegantulus and Phaner furcifer (see Sections 2.3 and 2.4 below). Martin (1972b), following Walker (1969), suggested that the tooth-scraper evolved in pre-Miocene times in Africa. Lorisiformes and Lemuriformes would thus have had a common ancestor for which gum eating would have been a vital strategy. The tooth-scraper is still very useful for such genera as Cheirogaleus, Microcebus, and Galago, allowing them to scrape inside small cracks of bark, around gum secretions, and to gather a large number of tiny droplets of gum efficiently. The large and strong tooth-scraper of Propithecus permits them to eat the bark and cambium of woody species (Richard, 1974).

Even more specialized is the anterior dentition of Hapalemur and Lepilemur, in which the upper incisors are greatly reduced, as in Hapalemur, or entirely absent, as in adult Lepilemur, in relation to their browsing habits. Further references and hypotheses concerning the evolution of the prosimian dental formula from the ancestral lemur/loris type $\left(\begin{array}{c}2 \\ 2\end{array} \frac{1}{1} \frac{3}{3} \frac{3}{3}\right)$, present in the Lorisidae and Cheirogaleidae,

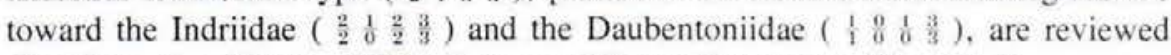
elsewhere (see Martin, 1972b; Petter and Petter-Rousseaux, Chapter 1)

One cannot expect the development of these dental characteristics to change as a function of any rapid change in the diet of the extant prosimian species. By contrast, the proportions of the different parts of the digestive tracts can rapidly follow change to an artificial diet (Hladik, 1967) and would eventually allow some flexibility (see Section 4.1 below).

A large cecum has been retained by those species feeding on gums while the folivorous species have either a very large cecum, or a large foregut, or both. By contrast, the smallest intestine sizes are found in the insectivorous species, in relation to diet concentrated in nutrients. These structural adaptations to diet and their more or less fixed patterns in the different taxonomic groups of prosimians, might be considered either as limits to the range of dietary variations in the most specialized species, or as adaptive tools enabling prosimians to compete with other species for a given ecological niche.

\subsection{Specialization in Relation to Ecological Niche}

The concept of ecological niche refers to specific structural adaptations as well as to the physiological and behavioral responses of the animal within its community and ecosystem. Biologically speaking the ecological niche could be presented as the "profession" of a given species (Odum and Odum, 1959); thus it could be defined almost entirely in terms of dietary specialization (for example, the primary consumer, or the predator, in a given ecosystem). By contrast the "address" of the same species would correspond merely to its particular habitat. An accurate definition of the niche concept was proposed by Hutchinson (1975), relating the multiple environmental parameters to a multidimensional hypervolume. Our present knowledge of primate ecology (Hladik and Chivers, 1978) does not allow the introduction of such a concept on a practical basis.

\subsubsection{Nocturnal and Diurnal Activity Rhythms}

There are a limited number of so-called "professions" practicable in a given habitat, because two species cannot share the same food resources, at least not to a very large extent (Gause's principle; Odum and Odum, 1959). This principle implies that during the long process of evolution, interspecific competition for food, if occurring, would result either in the total disappearance of one of the species, or to its adaptation to another type of available food. However, food resources are generally accessible round the clock and, for any particular category of diet, one can often find two different species, one feeding at night, and the other by day (CharlesDominique, 1975, 1977a). The activity rhythm can thus act as a mechanism ensuring ecological separation. The chances of obtaining food are equal for both species in this particular case and no selection factor can favor one of them.

As a matter of fact, the ancestral prosimians would have had to compete with many diurnal bird species feeding on insects and fruits, if the two classes of animal had had the same activity rhythm. This argument was presented by CharlesDominique (1975) to demonstrate that the early prosimians were nocturnal, of small size, and fed on insects, fruits, and gums. Later the diurnal primates evolved in Africa and Asia without competition from frugivorous/insectivorous birds, thanks to their particular foraging tèchniques (see Section 2.1.2 above), allowing access to invertebrate prey hidden in bark and dead leaves. In Madagascar the Lemuridae and Indriidae also evolved as diurnal forms, but essentially because they utilized particular types of food (such as seeds and hard pods), not accessible to birds and mammals lacking the necessary dexterity, as well as large amounts of leaves.

\subsubsection{Use of Different Locations in a Given Habitat and Seasonal Rhythms}

For different species of prosimian living in a nonhomogeneous environment, the " address" might be as important as the "profession." Two examples will illustrate these different systems allowing several sympatric species to feed on limited food resources. 
The first example concerns the evergreen forest of Gabon, near Makokou, where Charles-Dominique (1966, 1971a, 1974a, 1977a; Charles-Dominique and Bearder, Chapter 13) conducted his field work. The diets of the different species of nocturnal prosimian are presented in Fig. 4, according to the weight of stomach contents. Without going into detail (see next section) it is apparent that all the species feed on insects supplemented by a small amount of fruit, in the case of Arctocebus, or larger

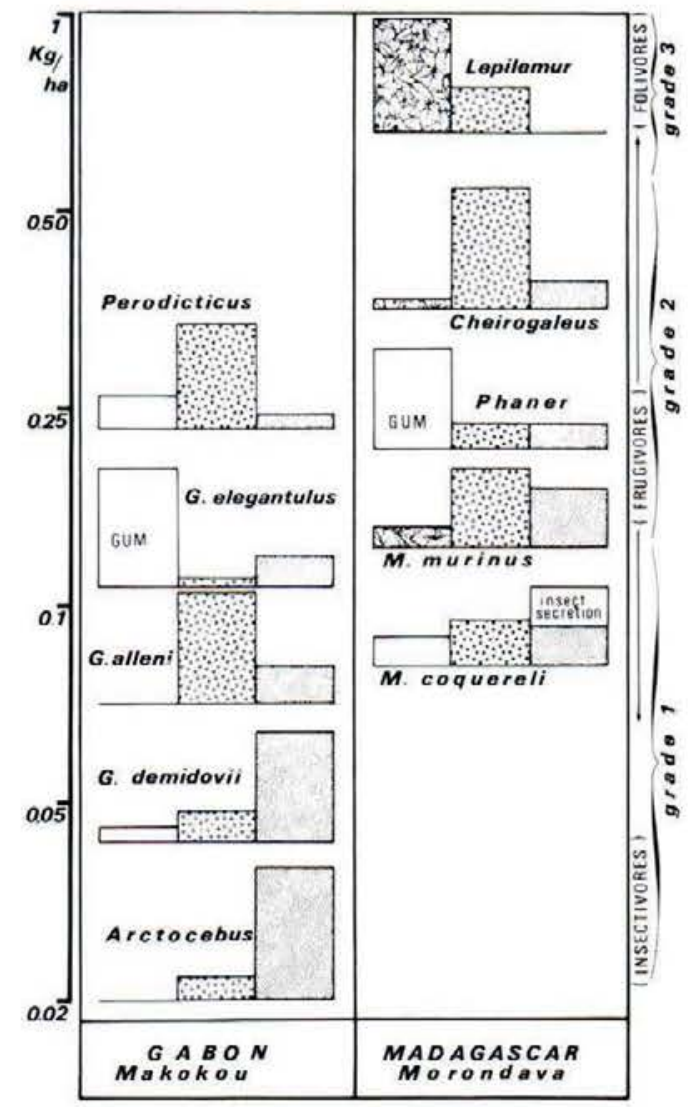

Fig. 4. Comparison of the natural diets of the five nocturnal prosimian species living in the evergreen forest of Gabon (Makokou area), with that of five species inhabiting the deciduous forest of the western coast of Madagascar (Morondava area). For each of the species the diagram represents the proportions of different food categories ingested in I year: leaves or gums, left rectangle; nectar, fruits, and seeds, center rectangle; insects and other prey, right rectangle. The three "grades" refer to the ecological significance of these diets, as presented in Section 2.2.3. The different species are located on a vertical scale with reference to the biomass observed in the field. The data concerning Makokou are from Charles-Dominique (1971a) and Charles-Dominique and Bearder (Chapter 13); while those from Morondava are from J.-J. Petter, P. Charles-Dominique, E. Pagès, G. Pariente, and C. M. Hladik (unpublished data) which yield a first rough estimate of the diet of the Malagasy species. amounts, in the case of Perodicticus and two of the Galago species, or gums, in the case of $G$. elegantulus. These five species utilize similar resources to a large extent, and would compete with one another, but for the operation of other factors, an example of which is the type of support on which the animals are generally observed in the rain forest.

Arctocebus calabarensis were generally observed on small lianas and bushes in the undergrowth of the forest. Galago demidovii were found in small lianas and in the foliage high up in the canopy. Galago alleni preferred vertical supports (small tree trunks and the bases of lianas) near the forest floor. Galago elegantulus were more at home on the larger branches, tree trunks, and lianas from low level to canopy. Perodicticus potto were observed on supports ranging widely in size in the canopy.

According to these observations, summarized in Fig. 5, certain species utilize a very small part of the habitat. Galago alleni, for instance, stay exclusively near the forest floor. Furthermore, the primary forest is not a homogeneous habitat, but a "mosaic" of different stages of growth, only $5 \%$ of which is truly mature (see A. Hladik, 1978). Arctocebus calabarensis live in the very young parts of this forest, in natural clearings, where the very dense and intricate vegetation constitute their preferred habitat. The three other species share the canopy of the forest but $G$. demidovii confine themselves to the small twigs and lianas in the thickest parts of the tree tops.

Other factors separating the species have to do with their different characteristic methods of finding and catching insects (see next section). The absence of competition can be related essentially to their concentration on different insect populations and fruits located in different parts of a nonhomogeneous forest.

The second example also concerns sympatric nocturnal species feeding to a large extent on similar resources, in a fairly homogeneous habitat-the dry deciduous forest of the west coast of Madagascar, near Morondava (a preliminary report concerning this study can be found in Petter, 1978). The diets of these prosimians can also be found in Fig. 4. A fairly large amount of insects is eaten by four of the sympatric species that could lead to competition for this limited food resource.

The main characteristic of the Morondava forest is the very important seasonal variation in food production. During the long dry season, lasting about 9 months, all trees shed their leaves, creating a shortage of food for primary consumers, especially for insects. By contrast, during the luxuriant rainy season, leaves grow quickly and insects are very abundant.

One of the prosimian species, Cheirogaleus major, relies entirely on the excess of production during the rainy season. For the remainder of the year they hibernate inside hollow trunks (Fig. 6A and B). Thus interspecific competition is avoided by a temporal factor rather than by spatial distribution of the different species. The food eaten by $C$. medius (which results in fat storage in the tail and under the skin) is sufficiently abundant during the rainy season to preclude competition from other species. 


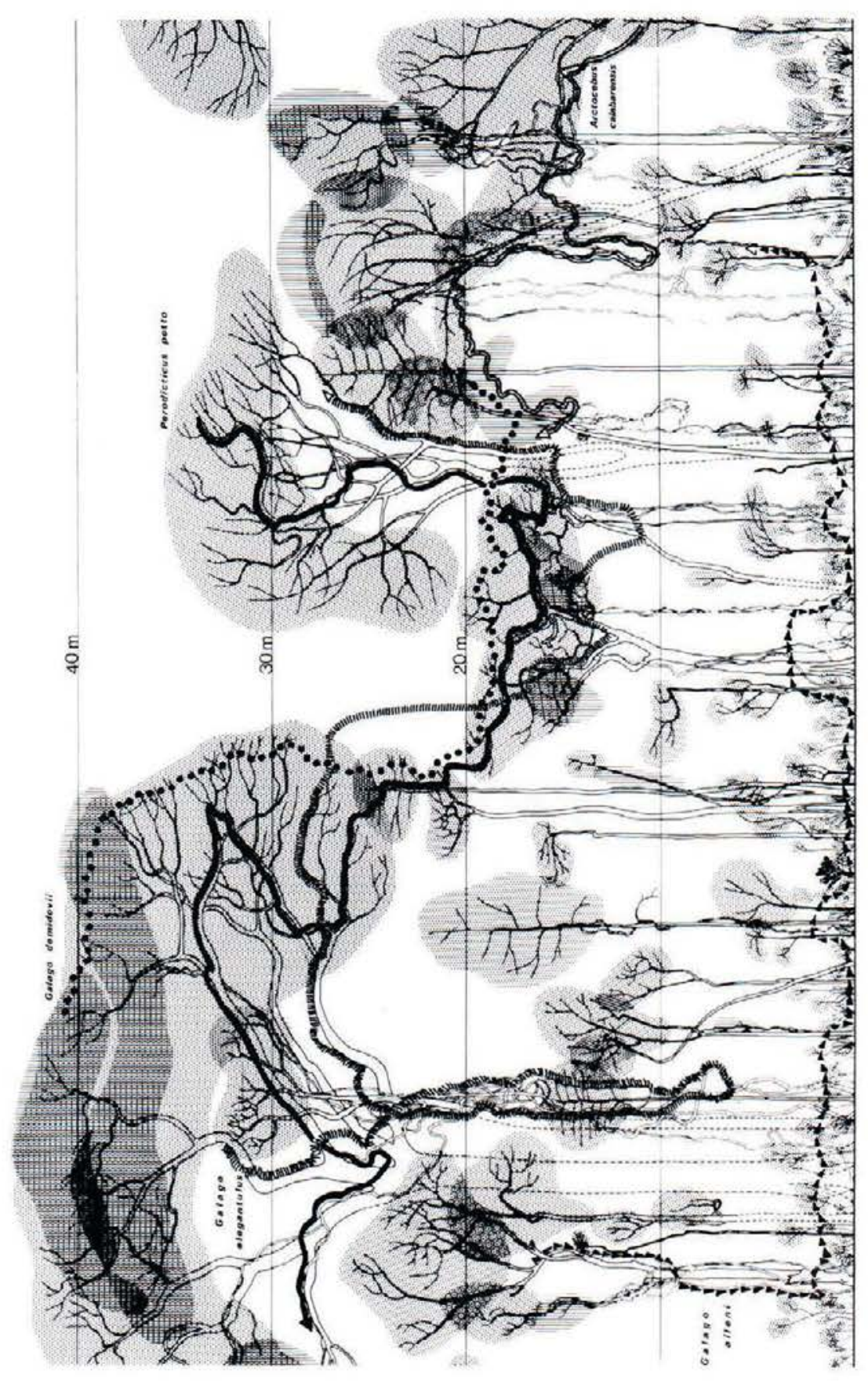

Microcebus murinus, to a lesser extent, also store fat in the tail during the rainy season, when many insects and fruits are available. Although they are less active during the dry season they do not truly hibernate.

Lepilemur ruficaudatus do not compete for food with the other prosimians since they are able to utilize tough foliage and a few fruits when available.

The other two species have developed unique strategies allowing subsistence throughout the year-utilization of the gums of some common trees by Phaner furcifer (Fig. 7A), and utilization of insect secretions (as well as dried secretions accumulated during the dry season) by Microcebus coquereli (Fig. 7B). Nevertheless, gums and insect secretions are only available in small quantities and can sustain only a limited population of nonhibernating prosimians.

\subsubsection{Food Resources in Different Ecological Niches}

According to the ecological significance of the diet, discussed in the previous section, prosimians as well as simian primates (Hladik, 1975) can be classified into three grades as follows:

Grade I: from the typically insectivorous forms, such as Loris and Arctocebus, toward species utilizing fruits and/or gums as a supplementary source of energy, in combination with the insects available (Microcebus, some Galago species, etc.).

Grade 2: species feeding on small quantities of insects and/or other prey, young leaves, fungi, or other vegetable matter, as a protein supplement to large amounts of fruits or gums which are the major sources of energy. This intermediate grade mainly includes simian species-Macaca, Cercopithecus, Cebus, and some prosimians such as Perodicticus and Cheirogaleus.

Grade 3: species feeding on fruits supplemented by leaves in sufficient quantity for protein balance, such as Lemur, and species eating more leafy parts and/or flowers, such as Propithecus and Hapalemur, to the most specialized folivorous forms, Indri and Lepilemur.

There is no absolute distinction between these classes, as shown by the examples in Fig. 4, but this progessive ecological classification allows more accurate definitions than terms such as "frugivore" or "omnivore" (which have been used to

Fig. 5. A reconstruction of the different types of itinerary utilized by the five nocturnal species living in the primary rain forest of Makokou (Gabon). The sample of forest represents a transect of $5 \mathrm{~m}$ in width (some trees, in broken lines, are located out of this section, after data from A. Hladik. 1978). The dotted areas represent tree foliage and the hatched areas represent lianas. The itineraries of the different prosimian species are based on the field work of Charles-Dominique (1966, 1971 a 1977a) conceming the height and the typical types of support where the animals are characteristically observed. Galago demidovii, on small branches and lianas in the canopy; $G$. elegantulus, looking for gums along smooth tree trunks and liana stems: $G$. alleni, jumping on the vertical supports of the undergrowth and catching insects on the ground; Perodicticus ponto. moving along large branches and lianas in the canopy: Arctocebus calabarensis, in dense vegetation, generally in the tree fall areas, where newly grown lianas and trees do not exceed $10 \mathrm{~m}$ in height. 
describe grades 1 and 2 diets as well as any diet which includes the flesh of large prey).

Each of the three grades is characterized by a major food type:

Grade 1: Insects (and/or small prey-invertebrates as well as vertebrates).

Grade 2: Fruits (and/or seeds and gums).

Grade 3: Leaves (and/or shoots).

These major types of food are available in limited amounts according to the primary production of the habitat.

Primary production of leaves is fairly constant in the tropics at 7 tons (dry weight) per hectare per year in a rain forest (A. Hladik, 1978). A deciduous forest has a smaller production, but the order of magnitude is the same at $3-4$ tons. The total production of fruits measured in the rain forest was around 0.5 tons per hectare per year. Insects collected in the litter at Makokou, representing an undetermined proportion of the total insect production (A. Hladik, unpublished data), yielded a figure of $23 \mathrm{~kg}$ per hectare per year. This is a classical pyramid of production, with the insects on top accounting for at least $1 / 200$ th of the leaf primary production.

At the very top of the pyramid would be the prosimians of grade 1, obtaining their energy from insects, together with other insectivorous mammals and birds sharing this resource. The biomass of such species is generally between 0.01 and $0.1 \mathrm{~kg}$ per hectare. The species of grade 2 have their major food type (fruits) available in larger quantity. As a result their biomass may be higher-between 0.1 and $1.0 \mathrm{~kg}$ per hectare. The folivorous species of grade 3 are able to reach the highest biomass$5.0 \mathrm{~kg}$ per hectare in the case of Lepilemur (Charles-Dominique and Hladik, 1971) and up to $15 \mathrm{~kg}$ per hectare in the case of folivorous simians.

In the examples presented in Fig. 4 the biomass of the species included in grade 1 increases in relation to the proportion of fruits in the diet (and decreases when the proportion of insects increases). There is a similar type of relationship between the food available and the biomass in the other grades. Thus, in each of these grades, the biomasses of different prosimian species follow the proportions of the major food types in their diets according to their availability in the natural environment. The intermediate levels, within each of the three ecological grades, can be indirectly shown by measuring the biomasses of a given habitat.

Other species of prosimian will be described below with reference to these ecological characteristics determined by food resources to which their specific patterns of feeding behavior have adapted.

\subsection{Prosimians of Asia and Continental Africa}

Whenever prosimians share the same habitat as monkeys and apes they occupy entirely different ecological niches (Bourlière, 1974). In Asia and continental Africa a limited number of nocturnal prosimians live in the same dense evergreen forest (rain forest) as well as in dryer habitats such as deciduous and semiarid shrub of the tropical and equatorial zones. Their nocturnal activity rhythm accounts for the separation of ecological niches from those of the diurnal simian primates. Other more subtle factors account for niche separation in a habitat shared by several prosimian species.

Only two Lorisinae and the three species of tarsier are present in Asia.

\subsubsection{Loris tardigradus (Slender Loris: Fig. 1)}

The slender loris is found in Sri Lanka and in India. Different subspecies are adapted to different habitats (cf. Hill, 1953). For instance, in Sri Lanka, L. $t$. nycticeboides, which have a very thick fur, inhabit the montane forest of the central districts of the island where low temperatures and permanent high humidity are the predominant climatic features. Three other subspecies are distributed in the various climatic zones, among which $L$. $t$, nordicus were studied in the field (Petter and Hladik, 1970), especially in the deciduous forest of Polonnaruwa.

This animal is relatively heavy $(0.25 \mathrm{~kg})$ if one considers its diet which includes only small amounts of fruit, the bulk of the diet being made up of insects and invertebrate prey (and, occasionally, geckos and small birds). This is due to the utilization of abundant prey (see Section 1.2 above) which are generally avoided by other mammals and insectivorous birds living in the same habitat. Loris $t$. nordicus utilize approximately 1 hectare of forest per individual: accordingly their biomass is about $0.2 \mathrm{~kg}$ per hectare, a very high figure for a predator.

Considering the distribution of males and females, one would expect the social structure of L. tardigradus to resemble that of Galago or Perodicticus (CharlesDominique, 1977b), each animal being generally solitary in its individual home range or territory. They move according to irregular patterns, a strategy utilized by most insectivorous primates (Hladik, 1975), which avoids localized destruction of the invertebrate prey, and thus allows a regular supply. Further investigations are necessary to confirm and elaborate on some of these socioecological observations of Loris.

The habitat of $L . t$. nordicus is restricted to the dense parts of the forest, where the animals move slowly along the lianas and thin branches. This particular locomotor pattern is partly a strategy to prevent detection by predators, but it also allows them to approach large insects sufficiently closely to grab them with the stereotyped movement of the hand described in Section 2.1.2 above. Like other Lorisinae, $L$. tardigradus utilize the olfactory sense more than do simian primates (see Schilling, Chapter 11), and detection of prey, when the animal moves slowly with its nose close to the branch, depends more on olfaction than on vision. The unpleasant smell of many invertebrate species, which is generally an antipredator device, is used by L. tardigradus to improve feeding efficiency.

\subsubsection{Nycticebus coucang (Slow Loris)}

The slow loris is a larger animal, weighing about $1.2 \mathrm{~kg}$, living in southeast Asia where different subspecies are adapted to different habitats. Nycticebus coucang 
might once have been sympatric with Loris tardigradus in the southern forest of India, where the latter species now occurs alone.

According to the field observations of Elliot and Elliot (1967) the feeding strategy of Nycticebus coucang is somewhat similar to that of Loris tardigradus-moving slowly along lianas and branches in a large home range in search of invertebrate prey, some of which have a repugnant smell and taste; but, owing to its larger size, the diet of $N$. coucang must be supplemented by large amounts of fruits. This different diet (the exact nature of which needs further field investigation) in combination with other ecological factors, such as those accounting for niche separation between Arctocebus and Perodicticus (Section 2.2.2), prevents competition in case of sympatry.

\subsubsection{Tarsius spp.}

The three species of tarsier ( $T$. bancanus, $T$. spectrum, and $T$. syrichta) are distributed exclusively on different islands of the Sunda archipelago (Hill, 1955, and see distribution map in Petter and Petter-Rousseaux. Chapter 1). Tarsius bancanus inhabit the lower strata of secondary as well as primary rain forest in Borneo (Fogden, 1974; Niemitz, this volume), Vertical clinging and leaping (Napier and Walker, 1967) between small trunks and lianas allows very rapid movements in this particular habitat.

The diet of $T$. bancanus mainly includes invertebrates such as Orthoptera and spiders, and some vertebrates such as geckos and other small lizards. There is no evidence that fruits are included in the natural diet, since the animal was observed near fruiting trees only to catch the insects attracted to the fruit. Some tests of food preferences on $T$. bancanus (Niemitz, Chapter 14) showed that the animal was also able to catch and eat venomous snakes.

In relation to this specialized diet the biomass of $T$. bancanus is lower than 0.05 $\mathrm{kg}$ per hectare. The animal weighs between 0.10 and $0.12 \mathrm{~kg}$, and has a home range of 3 hectares in some instances. The absence of nocturnal insectivorous competitors in the habitat of the tarsier presumably explains the persistence of such a form with an optical system of relatively poor efficiency (no tapetum lucidum; see Pariente, Chapter 10) which necessitates a considerable increase in the weight of the eyes and the dependent muscular system (including the neck) to allow efficient nocturnal vision.

In the rain forest of continental Africa the ecological specializations have allowed several nocturnal species of prosimian to inhabit the same area (see CharlesDominique and Bearder Chapter 13). The dietary characteristics of the five sympatric species of Gabon will be briefly described as a complement to the other features presented in Section 2.2.2.

\subsubsection{Arctocebus calabarensis aureus (Angwantibo)}

The angwantibo is the African homolog of Loris tardigradus. Arctocebus calabarensis inhabit the densest parts of the forest. Their particularly slow locomotor habit, when moving along lianas and small branches, is an effective device against detection by large predators as well as allowing close approach to invertebrate prey. In the rain forest of Makokou the diet of A. c. aureus includes a fresh weight average of $85 \%$ animal prey and only $14 \%$ fruit (see Fig. 4). The particular identity of the prey, determined by Charles-Dominique (1966) from the analysis of stomach contents, showed a very high proportion of caterpillars, some of which are protected by venomous hair. Before ingesting such prey, $A$. calabarensis force it through one hand, squeezing and extending it until most of the venomous hairs are broken. The other types of prey eaten, such as beetles, crickets, and ants, are also often rejected by other animals. As with $L$. tardigradus such a diet is not necessarily determined by preference (see Section 1.2 above) but is based on the ability to detect prey predominantly by smell, as well as the ability to tolerate prey repugnant to other species (Charles-Dominique, 1971a, 1972, 1974a, 1977a).

As a result of these ecological characteristics Arctocebus calabarensis aureus can maintain a body weight of $0.2 \mathrm{~kg}$, which is large for an animal feeding mainly on insects and quite similar to that of Loris tardigradus. Nevertheless, its biomass is very low at $0.005 \mathrm{~kg}$ per hectare (mean value) with a maximum of $0.015 \mathrm{~kg}$ per hectare in some areas. These low figures are deduced from the mean densities calculated by Charles-Dominique along pathways in the rain forest. If we consider, however, that $A$. calabarensis are restricted largely to natural clearings and small patches of rapid growth, that can be defined as "subhabitats" (see Section 2.2.2) in the rain forest, the biomass would be much higher in these local patches. Unfortunately there are, as yet, no reliable methods for studying separately and accurately each of the many parts of the mosaic structure of the primary rain forest. The total biomass of the prosimian species has to be considered in relation to the total food resources, in particular, the secondary production of insects and other small prey utilized by the prosimian species, for any comparison with other ecosystems.

\subsubsection{Perodicticus potto (Potto)}

Perodicticus rely on the same food resources as Arctocebus but eat a larger proportion of fruit $(65 \%)$, some gums $(21 \%)$, and only $10 \%$ animal prey (CharlesDominique, 1977a). This diet accords with its larger body size $(0.8-1.2 \mathrm{~kg})$ and the need to supplement with fruits and gums the relatively small amount of invertebrate prey that can be found in one night's activity. Ants (especially Crematogaster spp.) form the bulk of the prey supplemented by large beetles, slugs, caterpillars, spiders, and even centipedes that are avoided by the other primate species. The potto is the African homolog of Nycticebus coucang, of similar size and shape, the same slow locomotor behavior, and a comparable frugivorous diet supplemented by insects and other small prey rejected by other species.

Perodicticus potto are found in the canopy of the primary rain forest, moving along large branches in a more open "subhabitat" than that of Arctocebus calabarensis. Near Makokou the mean biomass of the potto, calculated after Charles-Dominique's observations along pathways, is $0.1 \mathrm{~kg}$ per hectare; but in 
particular areas, especially in more humid patches, the maximum biomass is as high as $0.3 \mathrm{~kg}$ per hectare. These figures, higher than in the case of $A$. calabarensis, are obviously determined by a diet including fruits as the major source of energy (grade 2, as defined in Section 2.2.3).

\subsubsection{Galago demidovii (Dwarf Bushbaby)}

Together with the two other Galaginae of the primary rain forest of Makokou, $G$. demidovii are very different from the two Lorisinae with which they are sympatric. They are the smallest of the prosimians of continental Africa (body weight, 0.06 $\mathrm{kg}$ ), and probably the most active, being able to leap and run very fast.

The diet of Galago demidovii includes an average fresh weight of $70 \%$ insects, $19 \%$ fruits, and 10\% gums (Charles-Dominique, 1974a, 1977a) and a very small amount of leaves and buds. The energy required by this active small form comes from the secondary production of insects and other small prey (grade 1 , as defined in Section 2.2.3) and, accordingly, the biomass is low at $0.03 \mathrm{~kg}$ per hectare, the animal occupying large home ranges of up to 3 hectares (Charles-Dominique, 1971b).

The "subhabitat" of $G$. demidovii is limited to the top of the canopy of the rain forest where they are usually found among small lianas and fine branches and where the potto, with its larger body weight, is not able to go. Thus $G$. demidovii have access to food resources largely inaccessible to the other sympatric Lorisidae. Nevertheless, food choice in $G$. demidovii is related largely to their strategy of rapid movement and fast running which allow them to capture large fast-moving insects such as moths and grasshoppers (cf. Charles-Dominique and Bearder, Chapter 13, Table VI). The stereotyped grabbing movement (see Section 2.1.2) of $G$. demidovii are particularly rapid and efficient, the animal being able to maintain its support by means of its legs. Furthermore, sonolocation of flying insects was deduced by Charles-Dominique (Charles-Dominique and Bearder, Chapter 13), the large mobile ears of $G$. demidovii being immediately directed toward relevant sounds. Hearing and sound detection of movements is more important than olfaction in the predatory strategy of this species.

Galago demidovii can escape rapidly from predators by leaping and running on small branches and, again, this active strategy is different from that of the Lorisinae which resort to passive avoidance by dissimulation and slow movements.

\subsubsection{Galago alleni (Allen's Bushbaby)}

Galago alleni have a feeding strategy very similar to that of $G$. demidovii but, as vertical clinging and leaping animals, they confine their activity to the undergrowth of the primary rain forest at low levels or on the forest floor (Charles-Dominique, 1974a; Charles-Dominique and Bearder, Chapter 13). The main types of prey, beetles and moths, are similar to those eaten by $G$. demidovii, but collected in a different "subhabitat," a peculiar type of niche separation which avoids competition for food resources.
The quantity of animal food found by Charles-Dominique in the stomachs of both species of Galago was, on average, fairly similar (about $2.0 \mathrm{gm}$ ). The relation between diet and body size (see Section 2.1.1) thus follows the general rule: Galago alleni, which are larger $(0.3 \mathrm{~kg})$, eat more fruits $(73 \%)$ as a supplement to prey $(25 \%)$. Other differences concern snails and frogs eaten only by $G$. alleni, and ripe fruits which have fallen to the ground and which are not accessible to $G$. demidovii. The biomass of $G$. alleni $(0.04 \mathrm{~kg}$ per hectare) in the primary rain forest of Makokou is probably limited by the availability of insects. In a recent study Charles-Dominique (1977b), using radiotelemetry, demonstrated that individual home ranges are very large-about 10 hectares for females and up to 50 hectares for males.

\subsubsection{Galago elegantulus (Needle-Clawed Bushbaby)}

Galago elegantulus have a very specialized diet including, on average, a fresh weight of $75 \%$ gums, 5\% fruits, and $20 \%$ insects (Charles-Dominique, 1974a) Gum eating is probably a primitive habit of prosimians (see Section 2.1.3 above) and, in the Makokou rain forest, Perodicticus potto and $G$. demidovii also feed on gums exuded by different lianas and tree species, but to a lesser extent than $G$. elegantulus. This species has peculiar morphological and behavioral adaptations, described by Charles-Dominique (1977a; Charles-Dominique and Bearder, Chapter 13), such as the clawlike nails, allowing access to gums along smooth trunks and large branches, a large "tooth-scraper," and a rigid behavioral pattern of using regular pathways to visit the different lianas and trees producing gums within the home range.

During these visits Galago elegantulus move in the canopy of the rain forest and may descend to visit certain lianas such as Entada gigas. They may catch some large insects, mainly grasshoppers, some large beetles, moths, and caterpillars. On an average, $G$. elegantulus eat as many insects as $G$. alleni, and both species have approximately the same body weight $(0.3 \mathrm{~kg})$; their biomass $(0.05 \mathrm{~kg}$ per hectare for $G$. elegantulus) is also fairly similar. As already stated, the total biomass of the three Galaginae feeding on insects, which is $0.12 \mathrm{~kg}$ per hectare, must be taken into consideration. This is about the same as the biomass for the two Lorisinae in the primary rain forest of Makokou. Together they constitute a biomass approximating that of Loris tardigradus in Sri Lanka $(0.2 \mathrm{~kg}$ per hectare). Food production has the same order of magnitude in the different forest types but, in the African rain forest, it must be distributed among a number of different specialized forms.

In the dry habitats of South and West Africa two species of Galago are represented, sometimes sympatrically, by different subspecies living in different climatic zones (Bearder and Doyle, 1974).

\subsubsection{Galago senegalensis moholi (Lesser Bushbaby)}

The lesser bushbaby is the same size as the largest Galago species living in the rain forest of Makokou (body weight $0.3 \mathrm{~kg}$ ) but they have a much higher biomass, 
about $0.2 \mathrm{~kg}$ per hectare, calculated on the basis of the average home range (Charles-Dominique and Bearder, Chapter 13). If calculated on the basis of population densities the biomass may be as high as $1.0 \mathrm{~kg}$ per hectare. These figures approximate the total biomass of the prosimians feeding on insects in the rain forest of Makokou.

The diet of Galago senegalensis (Sauer and Sauer, 1963; Charles-Dominique and Bearder, Chapter 13) includes large amounts of various insects, mainly butterflies, moths, and beetles (Doyle, 1974a, b). The gum of Acacia trees is eaten throughout the year and may represent the main source of energy (grade 2 diet).

\subsubsection{Galago crassicaudatus umbrosus (Thick-Tailed Bushbaby)}

Galago crassicaudatus were studied by Bearder (Charles-Dominique and Bearder. Chapter 13) in the riparian bush of the north east Transvaal where they occur sympatrically with Galago senegalensis. This large animal (body weight $1.3 \mathrm{~kg}$ ) also presents a very high biomass-about $0.3 \mathrm{~kg}$ per hectare (Bearder and Doyle, 1974) for one family group, but may be as high as $1.5 \mathrm{~kg}$ per hectare in high population density areas. The diet of $G$. crassicaudatus mainly includes fruits and gums (or sap) and only rarely large prey like reptiles and birds in some areas. Nectar and seeds are also consumed, as well as some insects. This diet, typical of grade 2 (as defined in Section 2.2.3), might tend, in some cases, toward a grade 3 diet, utilization of the primary production as the major source of energy, which would allow for the very high biomass reported.

Further field investigations will probably be necessary to specify more precisely some of these dietary parameters. In the habitats where the two bushbabies live sympatrically the mechanism of niche separation is based on the use of "subhabitats" similar to that resulting in the sophisticated mode of sharing food resources in the rain forest of Makokou. Galago senegalensis are localized in orchard bush, and G. crassicaudatus mainly in the riparian bush (Bearder and Doyle, 1974). The latter species have also developed certain strategies reminiscent of the slow movements of Perodicticus potto, that would result in food preferences different from those of $G$. senegalensis. Nevertheless, both species of Galago rely on gums as the main source of energy, at least in winter, when fruits and insects are scarce and subtle mechanisms must exist to prevent interspecific competition.

\subsection{Nocturnal Prosimians of Madagascar}

The examples presented below will be limited to the five species of sympatric prosimian living in the deciduous forest of the western coast of Madagascar (cf. Section 2.2.2), and to the unique case of Daubentonia madagascariensis. Recent field investigations of these species illustrate the relationship between behavior and physiological adaptation. The same relationship presumably applies to many othe prosimian species for which further field investigations are needed (Petter, 1978; Petter et al., 1977).

\subsubsection{Cheirogaleus medius (Fat-Tailed Dwarf Lemur)}

In the deciduous forest of the west coast of Madagascar, near Morondava, $C$. medius have a very high biomass $(0.5 \mathrm{~kg}$ per hectare) for a grade 2 species which include in their diet a large amount of insects. The high population density (about 4 animals per hectare) is a result of the seasonal availability of food resources in excess of the requirements of all the sympatric species (cf. Section 2.2.2; Petter, 1978).

The seasonal feeding strategy of Cheirogaleus medius (Hladik, CharlesDominique, and Petter, in prep.) is related to their unique physiology, probably similar to that of rodent species hibernating in the temperate zones (Jameson and Mead. 1964). A very rapid increase in the body weight from 0.12 to $0.25 \mathrm{~kg}$ during the rainy season is due to storage of fat in the tail, which increases in volume from 20 to $54 \mathrm{~cm}^{3}$, and under the whole skin. During the dry season $C$. medius hibernate in hollow trunks, where several animals pile together in small lodges of earth and decaying wood, a system which maintains moisture and a fairly constant temperature. They remain lethargic for 7 to 9 months, and lose about $100 \mathrm{gm}$ in body weight.

The diet of Cheirogaleus medius (Fig. 4) includes fruits and flowers (mainly the nectar of some flowers, very abundant in certain tree species), insects (mainly beetles), and a few leaf buds and gums. Flowers and nectar are used at the beginning of the rainy season, December and January (Fig. 6A), while fruits are the staple food in February and March.

\subsubsection{Microcebus murinus (Lesser Mouse Lemur)}

Microcebus murinus also have a seasonal feeding strategy, but less varied than that of $C$. medius. The activity of $M$. murinus decreases during the dry season, with torpid periods, but no true hibernation. Body weight varies from 0.05 to $0.08 \mathrm{~kg}$, and the volume of the tail varies from 5 to $20 \mathrm{~cm}^{3}$, after accumulation of fat at the end of the rainy season. In terms of diet, feeding strategy, and ecology, $M$. murinus are very similar to Galago demidovii; these two species representing an archaic type, probably close to the common ancestor of Malagasy and African/Asian prosimians (Charles-Dominique and Martin, 1970). The diet of $M$. murinus consists of a large amount of insects and other small prey, mainly beetles and spiders, but also occasionally tree frogs and chameleons. Fruits and flowers (and nectar) are also eaten in large amounts, with leaf buds, gums, and insect secretions in smaller amounts. In a different environment, $M$. murinus were observed feeding on leaves of Uapaca sp. (Martin, 1972a, 1973). Such an animal, deriving the major source of its energy from the secondary production (grade 1), but using most of the food types available, could be the ancestor of many more specialized forms.

Microcebus murinus are generally found in the dense parts of the forest environment, running and leaping rapidly among the small branches (Fig. 6C) and lianas. They are able to grab prey with stereotyped movements of both hands and to 


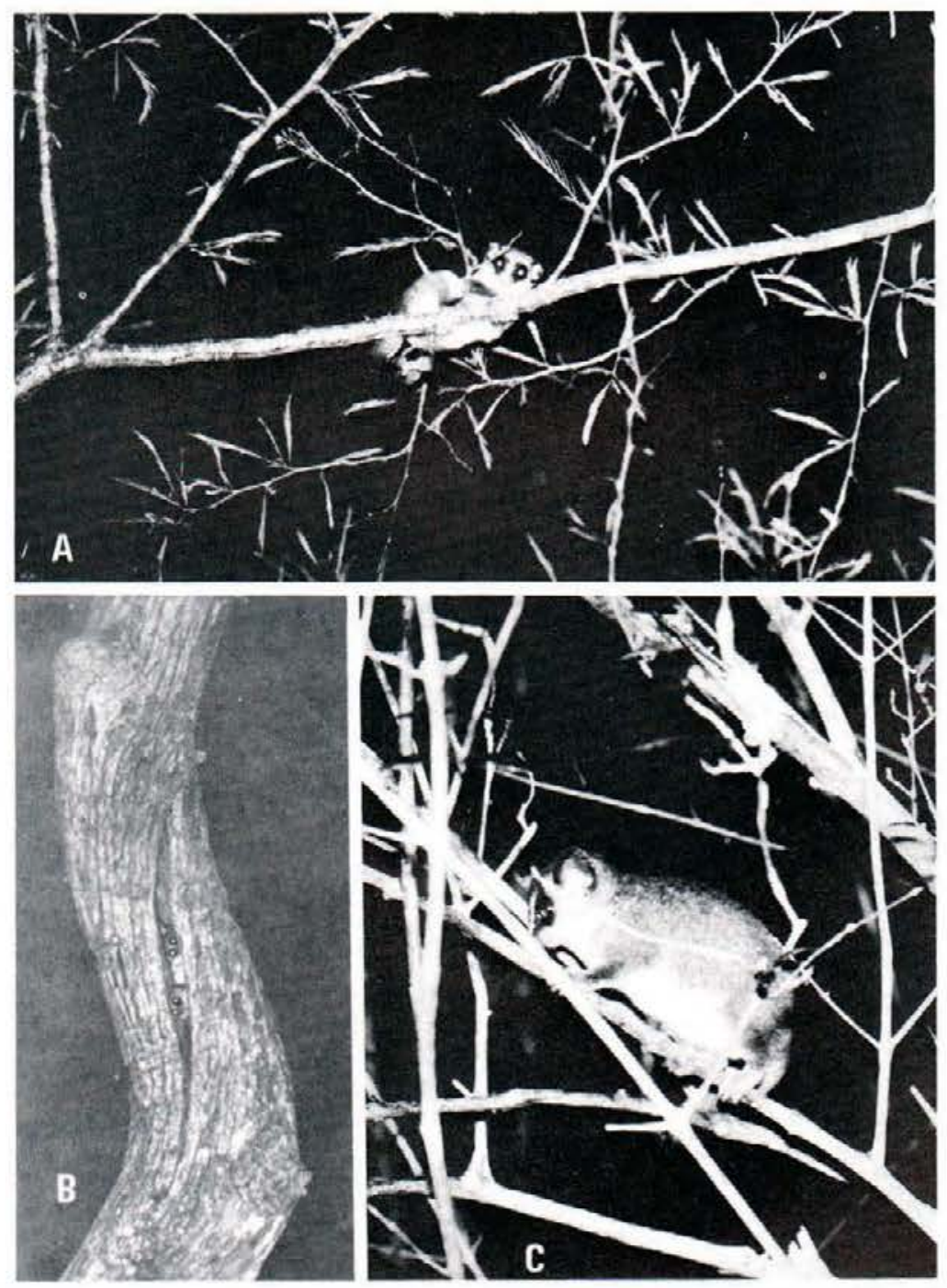

Fig. 6. Cheirogaleinae sympatric in the forest of the west coast of Madagascar, near Morondava. (A) Cheirogaleus medius foraging in the flowers of Mimosaceae. This animal was marked, after trapping, by shaving a part of its tail to allow individual identification. (B) At the end of the dry season Cheirogaleus medius were still in the hollow trunks where they had been hibernating for 7 to 9 months. (Photograph Hladik and Charles-Dominique.) (C) Microcebus murinus foraging in small twigs at a low level in the fores maintain balance at the same time by gripping the support with their feet only (Fig $3 \mathrm{~A}$ ). These combined rapid movements are also performed by Galago demidovii. Due to their greater speed $M$. murinus have access to certain types of prey, especially flying insects, unavailable to the slower Cheirogaleus medius in the deciduous forest of Morondava.

The population density of $M$. murinus is 4 animals per hectare in the Morondava forest, thus the biomass is around $0.2 \mathrm{~kg}$ per hectare. Very similar figures, 3.6 animals per hectare, were obtained in another dry habitat in the south of Madagascar (Charles-Dominique and Hladik, 1971). The biomass is very high if compared with other grade 1 species, which rarely exceed $0.1 \mathrm{~kg}$ per hectare. The seasonal use of excess food resources with a change in the level of activity during the season of scarcity is the physiological mechanism (although less marked than in the case of Cheirogaleus medius) which accounts for the wide distribution of $M$. murinus in Madagascar.

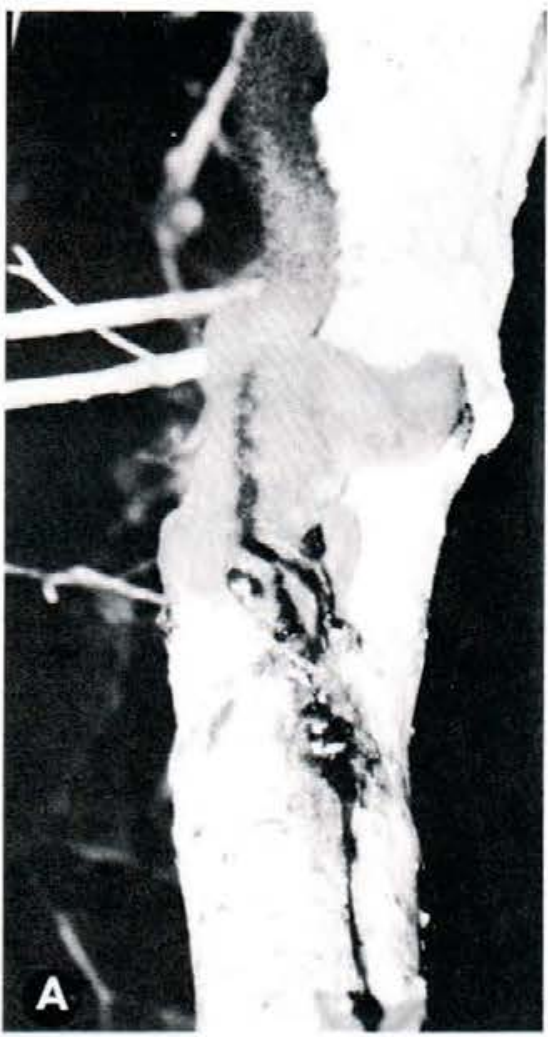

Fig. 7. Three other sympatric species of nocturnal prosimian in the deciduous forest near Morondava help of its tooth-scraper. (continued) 


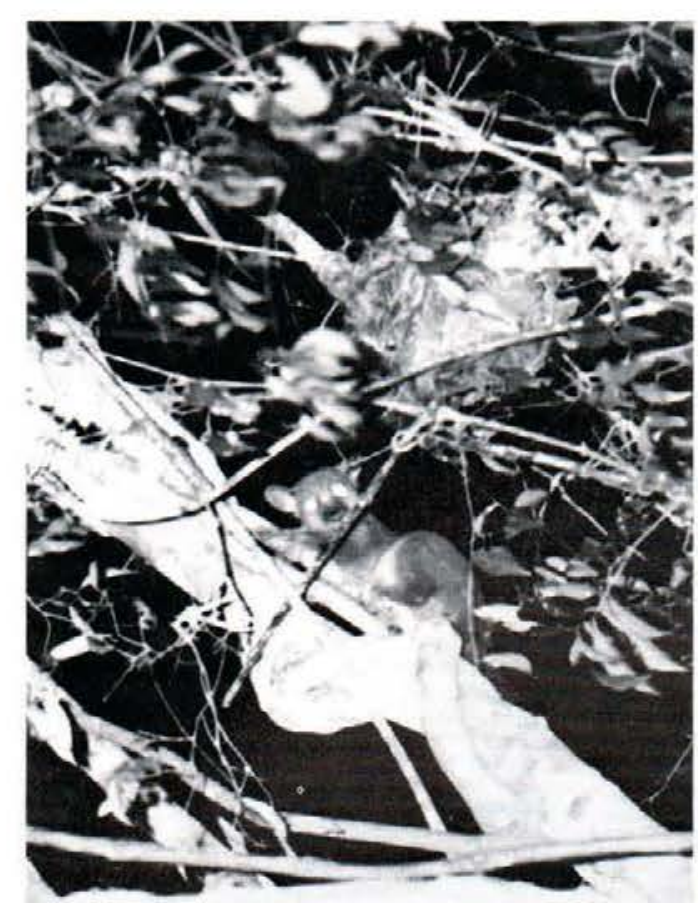

B

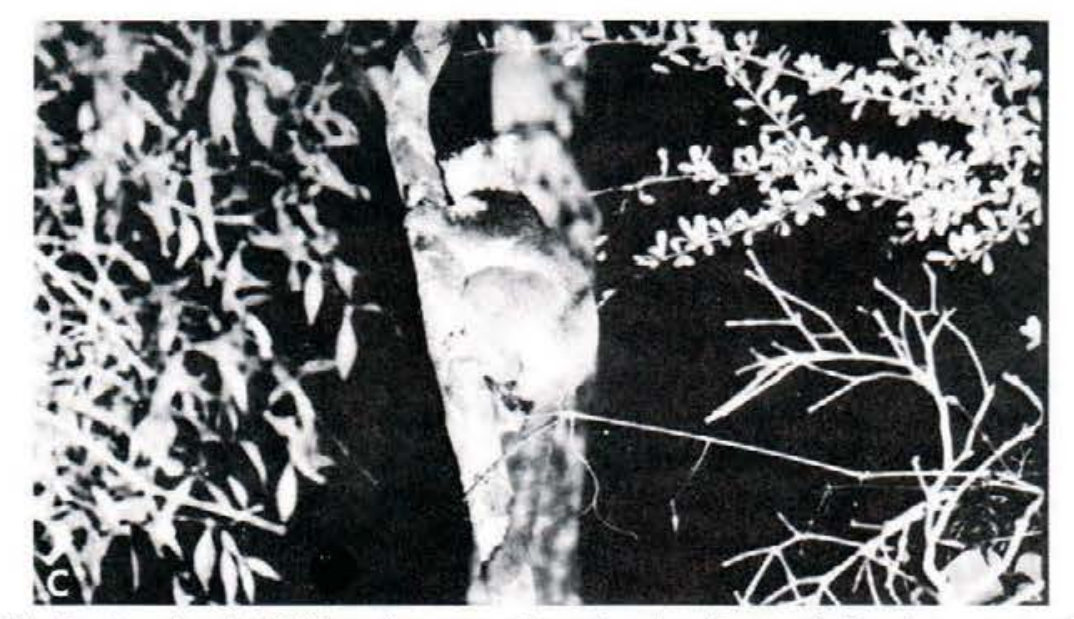

Fig. 7. (continued) (B) Microcebus coquereli moving along lianas to feed on the sweet secretion of Homoptera larvae: the nest is visible on the right side of the picture. (Photograph: J. J. Petter.) (C) Lepilemur ruficaudatus before leaping from a vertical tree trunk.

\subsubsection{Microcebus coquereli (Coquerel's Mouse Lemur)}

Microcebus coquereli, sympatric with the above two mentioned species in the forest of Morondava, have the lowest biomass (less than $0.1 \mathrm{~kg}$ per hectare), even if those parts of the forest used exclusively by this species are considered. For instance, Pagès (1978) found 2 males, 2 females, and 3 juveniles ranging over 17 hectares. Microcebus coquereli are generally found along rivers and near semipermanent ponds, where the forest is thicker and slightly higher (up to $20 \mathrm{~m}$ ) than in the dryer parts (Petter et al., 1971).

This animal, weighing $0.3 \mathrm{~kg}$, feeds on insects, some fruits, and some gums, but a large quantity of its energy is derived from particular insect secretions (Fig. 4). The activity of $M$. coquereli is constant throughout the year and there is no obvious seasonal variation in body weight. During the dry season they rely mainly on the sweet secretion of the larvae of Flatidae (Homoptera), spending up to $60 \%$ of their feeding time licking the branches around these larvae, and later looking for the dried secretions left by colonies of Homoptera, which have the appearance of large pieces of sugar and are also used by local human populations. The availability of this unique food, which may be considered part of the secondary production, is probably a factor limiting the population density of $M$. coquereli. During the rainy season, when other types of food are abundant, $M$. coquereli feed from the same sources as the other sympatric Cheirogaleinae, i.e., fruits, flowers, nectar, and insects, but probably also feed on larger prey (following the results of food tests in captivity) and may also catch and eat $M$. murinus.

Microcebus coquereli spend the daytime in spherical nests made of small twigs and leaves woven together, which serve as a protection against predators especially in the case of young animals.

\subsubsection{Phaner furcifer (Fork-Marked Lemur)}

Phaner furcifer are specialized gum eaters. As for the other species mentioned above, the availability of a particular food source throughout the year allows this animal to survive in the deciduous forest without any marked seasonal variation in body weight or activity (Charles-Dominique and Petter, 1978).

Phaner furcifer have many characteristics also found in the other specialized gum eaters, like Galago elegantulus (see Section 2.3.8 above), a fairly similar body weight $(0.3 \mathrm{~kg})$, a unique nail structure allowing them to descend smooth trunks to gain access to particular gum sites (Fig. 7A), and a large and horizontal toothscraper. Certain behavioral patterns are also convergent characteristics related to reliance on gum as a staple food, in particular, the efficient use of regular pathways to visit gum sources at the beginning of the night, all the gum-producing trees being located in the home range (see Pariente, 1975). In the Morondava forest a common tree species, Terminalia sp., is the main source of gum. It might be noted in passing that, during the daytime, one bird, Coua cristata, feeds on the gum of these trees, but not as effectively as $P$. furcifer (Charles-Dominique, 1976). The diet of $P$. furcifer also includes small quantities of insect secretion (from Homoptera larvae 
and from ladybirds), some fruits, and about $10 \%$ insects necessary to compensate for the low protein content of gums. The sap of the Baobab. Adonsonia sp., is also eaten during the dry season. The biomass of $P$. furcifer may be as high as $0.4 \mathrm{~kg}$ per hectare in the Morondava forest.

The total biomass of the nocturnal prosimian species feeding partly on insects (grade 1 and grade 2) in the Morondava forest, is much higher than in the rain forest of Makokou (see Fig. 4). The higher biomass of Morondava is not due to higher primary and secondary production, but may be due to the presence of other animals in Makokou, not shown in Fig. 4, like the diurnal simian primates, which do not compete directly with the prosimians (see Section 2.2.1 above), but which include large amounts of insects in their diets (grade 2). In Morondava, the diurnal lemur species (Propithecus verreauxi and Lemur fulvus) and Lepilemur ruficaudatus, have grade 3 diets; thus the food resources are shared by a smaller number of species, allowing higher biomasses of the particular forms adapted to the severe local seasonal changes.

\subsubsection{Lepilemur ruficaudatus (Sportive Lemur)}

Lepilemur are able to utilize the tough foliage of different tree species as their staple food. This ubiquitous material is almost totally absent during the dry season in the forest of Morondava, and it is not yet known what type of production determines the carrying capacity of this habitat at this time. The biomass of $L$. ruficaudatus exceeds $2.0 \mathrm{~kg}$ per hectare; its body weight of $0.8 \mathrm{~kg}$ and its population density is estimated at 3 animals per hectare.

In the bush of southern Madagascar the biomass of Lepilemur leucopus is $2.1 \mathrm{~kg}$ per hectare (Charles-Dominique and Hladik, 1971) and is limited by the availability of the flowers of two species of Alluaudia, which constitute the main food source during the dry season, but the biomass of the same species of Sportive Lemur may exceed $5 \mathrm{~kg}$ per hectare in the gallery forest where leaves are available throughout the year. A unique physiological adaptation, cecotrophy, allows the different species of Lepilemur to digest a sufficient proportion of these foods which are particularly poor in nutrients (see Section 4.2 below). The activity of these animals is minimal and less than 10\% of their energy is spent in moving to feeding sites (Hladik and Charles-Dominique, 1974) within a very small territory (see Section 3.1 below). Most of their time during the night is devoted to immobile surveillance of the borders of their territories defending small food resources.

\subsubsection{Daubentonia madagascariensis (Aye-Aye)}

Daubentonia are remarkable for their unique feeding strategy enabling them to feed on wood-boring grubs. The absence of any representative of the woodpecker family has left vacant an ecological niche for which Daubentonia have become specialized, enabling them to monopolize a readily available source of food (Petter and Peyrieras, 1970a)

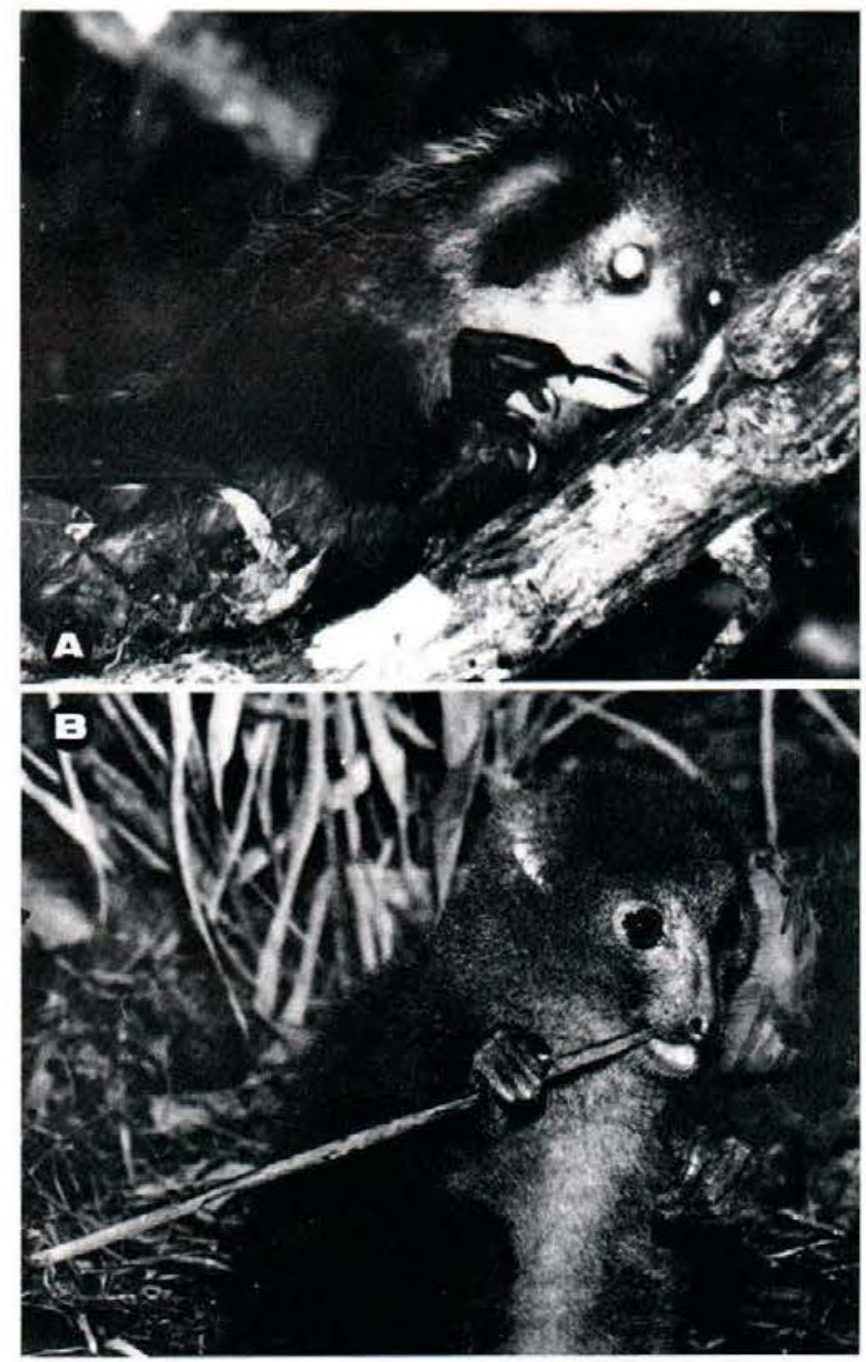

Fig. 8. Specialized prosimian feeding techniques. (A) Daubentonia madagascariensis feeding on a wood-boring grub. The superficial wood of the branch is bitten off with the incisors and the grubs are crushed inside the hole with the thin third digit which is then rapidly licked. (Photograph: J. J. Petter.) (B) Hapalemur griseus are specialized for feeding on bamboos but can be adapted to a common grass, Dactvlis glomerata. While feeding on this grass they handle it with stereotyped movements. (Photograph: C. M. Hladik. 
Daubentonia were observed in the rain forest of the east coast of Madagascar (Petter, 1962; Petter and Petter-Rousseaux, 1967; Petter and Peyrieras, 1970a). Their diet includes a large amount of fruits supplemented by insect larvae. The larvae are detected by smelling and hearing the insects inside decaying wood, the large ears of the aye-aye being directed toward the source. The wood is then bitten and the superficial parts are removed by means of the very strong and sharp incisors When the larvae are found they are crushed inside the hole by means of the very thin and elongated (relative to other prosimians) third digit and extracted in the form of juice by rapid movements of this finger which is licked at each stroke (Fig. 8A). A similar technique is used to drink and eat the young pulp inside a coconut, after making a small hole with the incisors. Other types of fruit are eaten by more classical methods.

Since Daubentonia, weighing about $2.0 \mathrm{~kg}$, include a large amount of insect larvae in their diet, the home range must be large enough to provide a sufficien amount of this resource. Petter and Peyrieras (1970a) observed one male with a female and a juvenile ranging in an area of about $5 \mathrm{~km}$ in length. The biomass might, therefore, be smaller than $0.01 \mathrm{~kg}$ per hectare, which is the order of magnitude found for other insect eaters of the rain forests.

\subsection{Diurnal Prosimians of Madagascar}

Where the diurnal prosimians of Madagascar fill ecological niches occupied in other parts of the world by simian primates they show a high degree of convergence but they are by no means exactly similar to simians (Charles-Dominique, 1977a). Many morphological and physiological differences, some of which are discussed in Section 2.1 above, have not permitted the evolution of certain feeding strategies characteristic of simian primates. A limited number of examples will be presented to illustrate the main types of diet of the diurnal prosimians.

\subsubsection{Lemur catta (Ring-Tailed Lemur)}

Lemur catta are a large frugivorous species supplementing their diet with a large amount of leaves (Fig. 3C). In natural conditions $L$. catta have only rarely been observed feeding on insects (Jolly, 1966). Young leaves and shoots are, therefore, a necessary supplement to fruit protein. In terms of number of observations their "diet" consist of $70 \%$ fruits, $25 \%$ leaves, and $5 \%$ flowers. This diet, based on primary production (grade 3 ), allows the very high population density observed in the gallery forest of the south of Madagascar. One group of about $20 \mathrm{~L}$. catta was calculated to have a home range of 5.7 hectares, thus the biomass may be as high as $7 \mathrm{~kg}$ per hectare. This high population and the ranges of the different groups were maintained with very little change over several years (A. Jolly, personal communication).

\subsubsection{Lemur fulvus (Brown Lemur)}

Lemur fulvus were studied by Sussman $(1972,1974)$ in a deciduous forest of the southwest of Madagascar where they live sympatrically with $L$. catta. These two species have different feeding strategies enabling them to share the available food resources. Lemur fulvus live in small groups (about 10 animals) in small territories of about 1 hectare and feed in the canopy of the most common plant species $(80 \%$ of the feeding observations concerned only three species of plant). Leaves form the bulk of the diet ( $89 \%$ of the feeding observations) but some fruits $(7 \%)$ and flowers $(4 \%)$ are also eaten.

In this same area $L$. catta form larger groups (an average of 18 animals), ranging - over larger territories ( 9 hectares) and feed on some plant species that are not evenly distributed. A large part of the foraging time is spent on the ground or near the forest floor. A large amount of leaves are still eaten ( $44 \%$ of the feeding observations), but fruits $(34 \%)$, some flowers $(8 \%)$, and herbs $(15 \%)$ are also eaten (cf. Section 2.5.1 above).

The very high biomass of folivorous primates in the particular habitat is surprising, reaching $25 \mathrm{~kg}$ per hectare $(20 \mathrm{~kg}$ for the most folivorous species and $5 \mathrm{~kg}$ for the most frugivorous ones). This ecological system, enabling two sympatric species, of similar morphology and fairly similar body weight (both species weigh about $2.5 \mathrm{~kg}$ ), to share the resources, parallels the system found in Sri Lanka, regarding two sympatric species of leaf monkey (Hladik and Hladik, 1972; Hladik, 1977 a). One species, in small groups, feeds on the most common plants in small territories; the other species, in large groups, feeds on unevenly distributed resources in large territories with a total primate biomass of $27 \mathrm{~kg}$ per hectare. These figures are the maximum biomasses ever recorded for primates.

\subsubsection{Propithecus verreauxi (Sifaka)}

Propithecus verreauxi, another large folivorous and frugivorous species, share - the food resources with Lemur catta in the forests of the south of Madagascar. Propithecus verreauxi play the same ecological role previously described for $L$. fulvus. Groups of sifakas are small (about 5 individuals), living in territories of approximately 2 hectares and sharing the most evenly distributed tree species (Richard, 1973). In terms of number of feeding observations the "diet" of $P$. verreauxi consists of $65 \%$ fruits, $25 \%$ leaves, and 10\% flowers (Jolly, 1966).

\subsubsection{Hapalemur griseus (Gray Gentle Lemur)}

Hapalemur griseus are adapted to a marshy environment where bamboo grows. They live in small groups and feed mainly on bamboo shoots (Petter and Peyrieras, 1970b, 1975) and, presumably, to a lesser extent, on fruits. Their technique for handling food, and particularly the pieces of grass, is the stereotyped grabbing movement characteristic of other prosimians (Fig. 8B). 


\subsubsection{Indri indri (Indri)}

Indri indri were recently studied in the field by Pollock (1975, and Chapter 9) in the rain forest of the eastern coast of Madagascar. Indri, the largest of the extant prosimians, with a body weight of over $10 \mathrm{~kg}$, have a folivorous diet but a fairly low biomass of about $1.0 \mathrm{~kg}$ per hectare (calculated from the data of Petter and Peyrieras, 1974). This low biomass can be explained by a folivorous diet which includes only a very small quantity of mature leaf material. From Pollock's (1975, 1977) observations $50-75 \%$ of the feeding observations concerned young leaves and buds, $25 \%$ fruits (including 10-15\% unripe seeds), and mature leaves featured in less than $1 \%$ of the feeding records. Some earth was also occasionally eaten (see Section 6). Mature leaves are an ubiquitous source of food in the forest, but young leaves are represented only in small amounts generally scattered on deciduous trees and locally available for short periods only (A. Hladik, 1978).

Nevertheless, if one considers the biomass of all arboreal folivores in this rain forest, it will be around $6 \mathrm{~kg}$ per hectare, a classical figure which is partly explained by the complexity of this environment divided into subtle ecological niches.

\section{SOCIAL LIFE IN RELATION TO DIET AND ECOLOGY}

\subsection{Home Range, Territory, and the "Supplying Area"}

The notions of home range and territory are generally clearly understood in different field studies concerning individual prosimians as well as groups (see elsewhere in the present volume). The inventory of food resources available to each

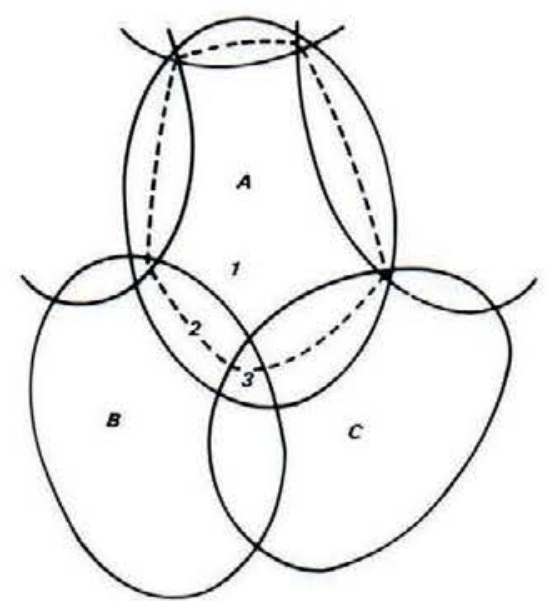

Fig. 9. The "supplying area" of group A, as determined hy the limits of the home ranges of the other groups $\mathrm{B}$ and $\mathrm{C}$. etc., is shown by the broken line. group (or to individual solitary prosimians) calls for a clear definition of what is actually available to each of them in the overlapping parts of the home ranges.

If Fig. 9 is taken as a theoretical example of the home ranges of three groups of primates, A, B, and $\mathrm{C}$, then $\mathrm{A}$ will have exclusive access to the food resources in the core area 1 . This central area, if defended, will be considered a territory. In area 2 , where the ranges of $\mathrm{A}$ and $\mathrm{B}$ overlap, an equivalent amount of food will be

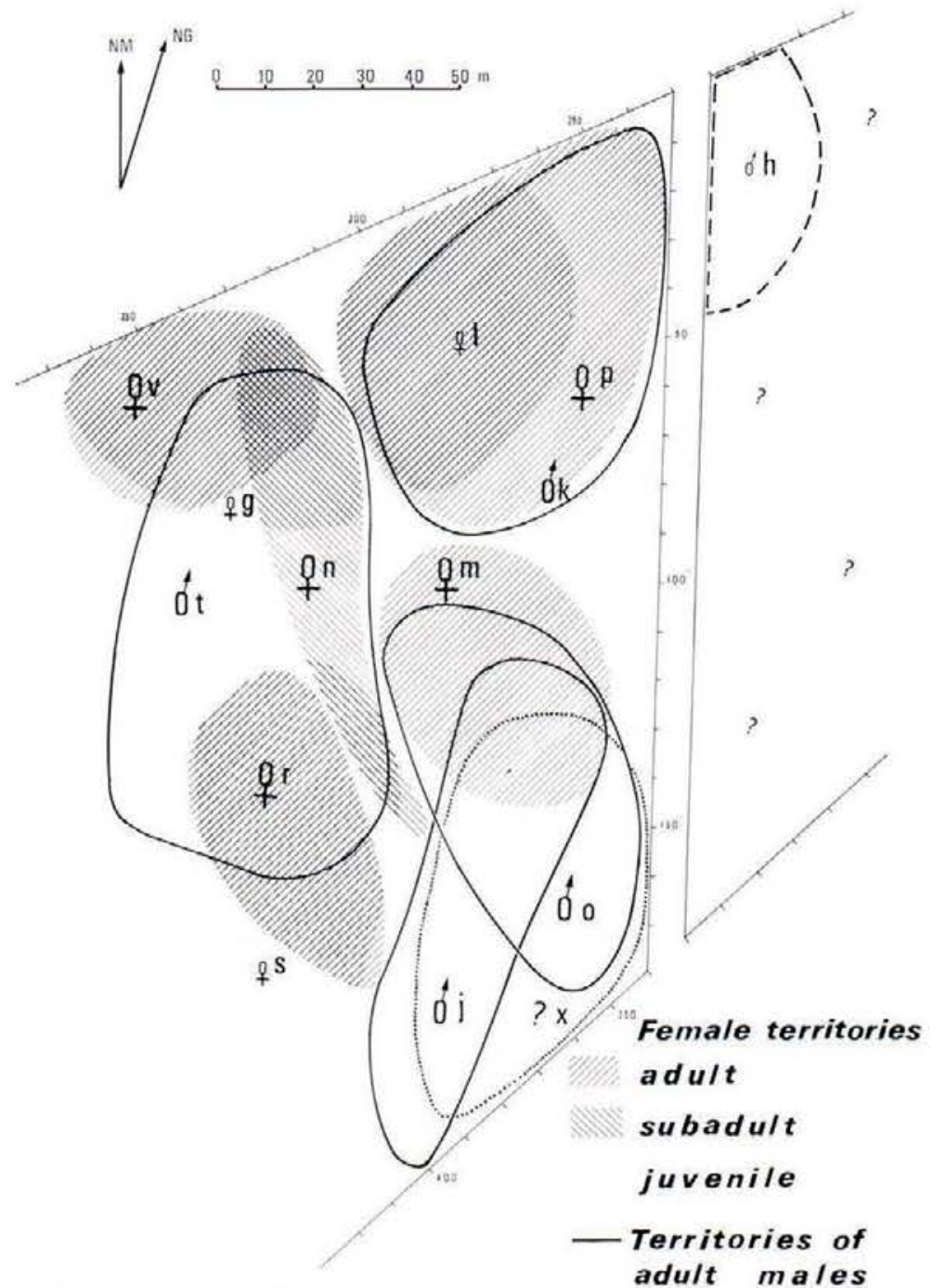

Fig. 10. Habitat utilization by Lepilemur leucopus at Berenty in southern Madagascar, as shown by the limits of the individual territories of females and males. (After Charles-Dominique and Hladik, 1971. 
available to each group, irrespective of the dominance relationship between the groups, as shown by their territorial behavior, since field observations have shown that groups ranging in the same area eat approximately the same quantity (Hladik and Hladik, 1972; Hladik, 1977a). In area 3, where the home ranges of all three groups overlap, one third of the food will be available to each group. The limit of the "supplying area" (dashed line in Fig. 9) is purely fictitious, but is convenient and necessary to calculate the quantity of food available to each group in an homogeneous environment.

The size of the supplying area of one group of diurnal prosimians (as well as that of the supplying area of one individual nocturnal prosimian) is determined by the diets of the different species allowing even distribution of food resources in the population, even during periods of shortage. For example, it has been demonstrated (Charles-Dominique and Hladik, 1971; Hladik and Charles-Dominique, 1974) that, in a population of Lepilemur leucopus, in the territories which are shown in Fig. 10 , the supplying area of each individual may contain only 1.6 times the amount of food that is actually eaten during the period of maximum shortage. Such a social system, which allows a maximum population density according to the size of the individual territories, prevents any significant mortality during the period of food scarcity

The biomasses in relation to the different grades of diets, illustrated by many examples in Section 2, have been determined as a result of the selection of social mechanisms regulating the size of the supplying area. The maximum biomasses in habitats where populations are stablized, are generally determined by the production of the major food types (Section 2.2.3 above), but the pattern of distribution of food resources also influences the distribution of the species feeding on these resources.

\subsection{Social Patterning in Relation to Habitat Utilization}

Any type of food source (mainly fruit trees) may be considered as evenly distributed only in terms of a particular scale. For example, approximately the same number of trees of a very common species may be found in each of two adjacent home ranges of 1 hectare, while a rare tree species might be found by chance in only one of them. Rare tree species are likely to be evenly distributed between adjacent home ranges only if they are very large, say 100 hectares or more. Because type of diet has a limiting effect on the maximum possible biomass of a given habitat, prosimian species living in large groups will have a large supplying area that may include several uncommon tree species in sufficient number to be utilized as a food source. By contrast, another prosimian species, of the same ecological grade, bu living in small groups, will have a small supplying area in which only the most common tree species can be considered as a potential food supply.

The example of the two sympatric Lemur species studied by Sussman (Section 2.5.2) illustrates this principle of a feeding strategy depending directly on social structure. This interdependence must have been a strong selective pressure for the evolution of social structure in groups of prosimians as well as in groups of simian primates with converging structures (Hladik, 1975, 1977a, 1978). There are, of course, more complex combinations. A very large home range with a relatively smal supplying area might permit the use of scattered resources by several groups of relatively small size. Even in nocturnal prosimian species, there is a relationship between diet and social structure because of their different overlapping systems (Charles-Dominique, 1974b, c, 1978).

\subsection{Food Traditions and Learning}

The prosimian infant clinging to the fur of its mother starts its feeding education by taking fragments of fruits or insects from the hand or from the mouth of the mother. These fragments generally have little nutritional value. For instance, a young Perodicticus potto takes only the leg of an insect and chews or sucks it (P. Charles-Dominique, personal communication), but the perception of a particular taste is almost certainly of paramount importance as a basis for future feeding behavior. The acceptance of "repugnant" prey by the adult $P$. potto probably starts from this early conditioning.

The juvenile Microcebus coquereli approaches its mother with its head turned on its side below its mother's head and is allowed to take some parts of the prey (Fig. 11A). It thus learns the taste of a large number of different kinds of prey before it reaches adult size (E. Pagès, personal communication). The juvenile Galago elegantulus was directly observed by Charles-Dominique following its mother along the woody stems of Entada gigas to eat the gum exuded by this vine. As soon as the mother began to feed on the gum, the juvenile rushed to her side to collect some. The young Lemur, while still suckling, plays around the mother and occasionally collects and tastes a few leaves (Fig. 11B).

During the major part of its first year, the young prosimian may learn the various types of food available during different seasons in its habitat by observing the behavior of its conspecifics. The young Galago demidovii, for instance, for a period of 6-8 months, may follow its mother at a close distance, or it may follow another female associated with its mother, or it may follow the dominant male (CharlesDominique, 1971a, 1977a, personal communication).

Behavior is very flexible during the early period of learning and feeding behavior may alter radically following an unpleasant experience. For instance, after a young Galago alleni had been badly irritated when trying to eat a female butterfly Anaphe $s p .$, it avoided all butterflies for several weeks. This last observation of CharlesDominique (1977a) follows the general principle of aversive conditioning which applies to any vertebrate and can be induced by an "internal" reaction to food (i.e., the illness following absorption, as discussed by Garcia et al., 1974; see also Section 5.1). As a matter of fact, learning supposes more subtle possibilities of discrimination and extinction. 

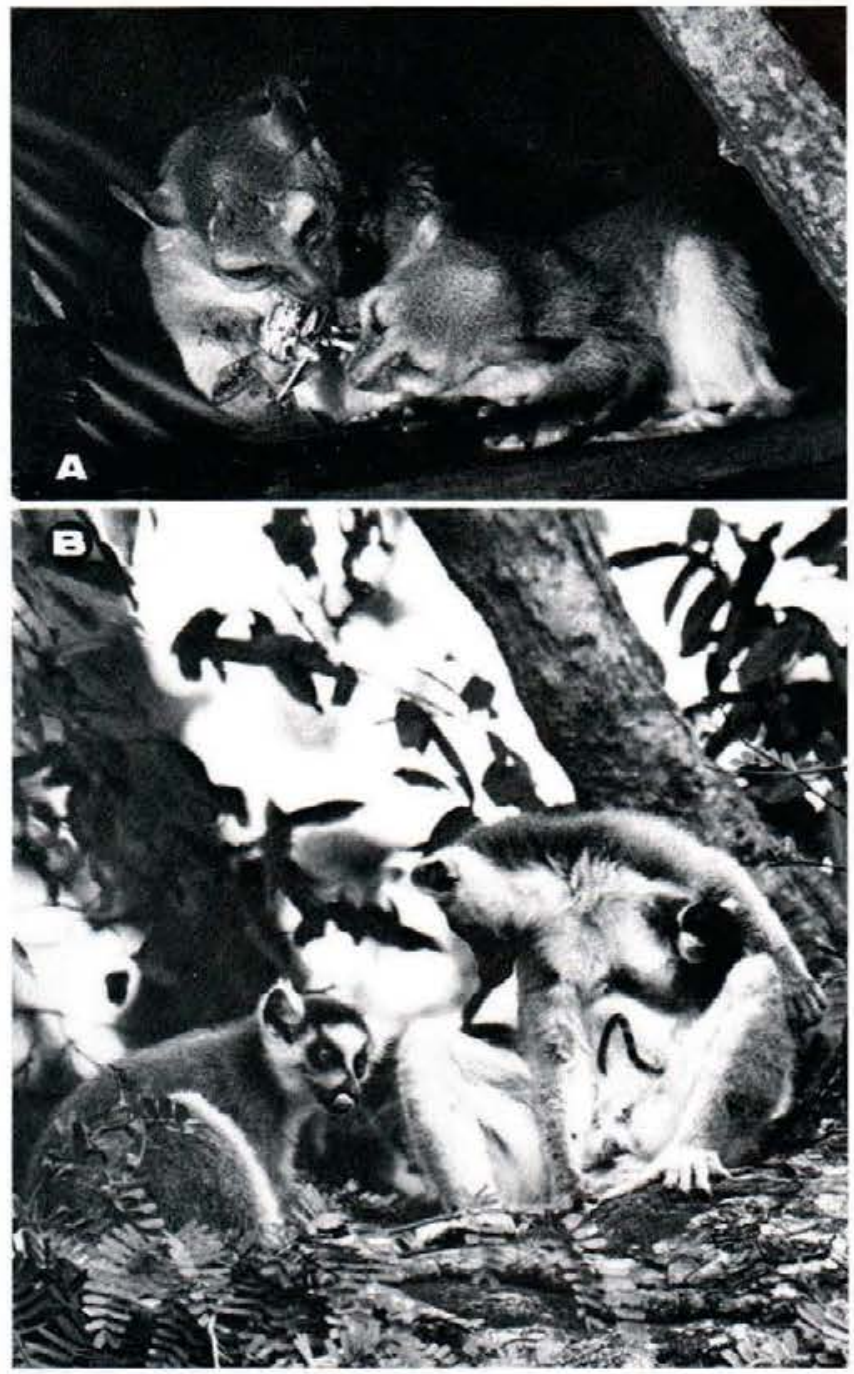

Fig. 11. Young prosimians during their first natural food tests. (A) Microcebus coquereli taking some pieces of a locust being eaten by its mother. (Photograph: E. Pagès.) (B) Lemur catta, still clinging to the fur of its mother in a tamarind tree at Berenty in southem Madagascar, can grab pieces of food and taste them. (Photograph: C. M. Hladik.)
Although there seems to be very little difference in visual discrimination learning among the various prosimians (and among many other vertebrates), significant differences appear to exist in the ability to adapt learned responses to changes in the visual situation. This ability seems to be the beginning of a higher degree of behavioral flexibility developed in some nocturnal forms (Cooper, 1978 and personal communication) and most diurnal forms thus far tested (Wilkerson and Rumbaugh, Chapter 6). Interspecific differences in learning and extinction have probably been selected as a result of the need for each species to adapt to the particular characteristics of its own ecological niche.

The gregarious species have inherent advantages for learning during longer periods than the more solitary forms. In groups the young may learn food choices, temporal patterns, and other important strategies from other juveniles and adults. A "group memory," which may partly substitute for individual memory, plays an important part in the development of social tradition. Habitat utilization can be very sophisticated, particularly the seasonal exploitation of a large number of uncommon food species

\section{PARTICULAR ASPECTS OF DIETARY SPECIALIZATION}

\subsection{Flexibility in Different Types of Diets}

Many field studies of prosimian ecology have shown that several types of habitat can be utilized by a given species. Some species are more adaptable than others and, in many cases, populations of the same species are sufficiently different in a large enough area such as to constitute different subspecies, e.g., subspecies of Loris tardigradus, Galago senegalensis, and G. crassicaudatus (see Section 2.3).

Some other species, such as Microcebus murinus, occurring in the south of Madagascar and in different deciduous forests along the west coast, and Galago demidovii, occurring in large areas of the rain forest in Central and West Africa, do not show such obvious local differentiations. Nevertheless, there are many differences in the habitats that certain species can use, especially in terms of the available food, its rate of production, the number of edible plant species, etc. Such prosimian species can be considered as more adaptable than those localized in a restricted geographical range and a particular habitat.

There are several other possibilities of variation in the natural diet of a given species. If we consider the five sympatric nocturnal prosimian species studied by Charles-Dominique in the rain forest of Makokou (Sections 2.2.2 and 2.3.4-2.3.8), all the examples given were concerned with the primary rain forest. The five species also inhabit the secondary forest and Charles-Dominique, in the various sources cited, presents the data collected in this particular habitat. In spite of the close proximity and similar climatic conditions in these two habitats, the plant species are 
almost entirely different, and the entomological fauna partly different; thus the composition of the diets of each of the prosimian species varies between the two habitats.

Seasonal variations, in relation to availability of food, are also very important: in many cases the seasonal difference in the diet of a given species is greater than the difference between two species at a given time. This has been shown for simian primates (Hladik, 1977a) and, according to the feeding records and feeding times reported by Jolly (1966) and Richard (1973) for Lemur catta and Propithecus verreauxi, respectively, it also appears true for lemur species. In the Cheirogaleinae, with the exception of Microcebus coquereli, these marked seasonal variations in the diet (Sections 2.4.1 and 2.4.2) are correlated with physiological cycles (Perret, 1972, 1974; Petter-Rousseaux, 1974) and, in captivity, the seasonal variations in food intake still occur even when the food supply is maintained unchanged (Andriantsiferana and Rahandraha, 1973; Petter-Rousseaux and Hladik, in press).

Important changes in the diet necessarily occur when prosimians are maintained in captivity. Major changes can be made without difficulty in species generally considered most adaptable in the wild, such as those of the genera Lemur and Galago. Other species, such as Indri, Propithecus, Lepilemur. Phaner, and Cheirogaleus, more specialized in their natural diets, have difficulty in adapting to, and rarely reproduce, in captivity. Lepilemur ruficaudatus, Propithecus verreauxi, and Cheirogaleus medius have only recently reproduced in the laboratories of Duke University and Brunoy, and Phaner furcifer have never bred in captivity.

Species feeding on ubiquitous resources, such as leaves, or on food available throughout the year, such as gums, do not require much flexibility in their diets, provided the composition of the food ingested is sufficiently regular to maintain bacterial flora in the gut. Although they are not adapted to sudden changes, this does not mean that they are more vulnerable than the more adaptable species: on the contrary, in their natural habitat, they are more efficient than any competitor and can maintain a very high biomass.

Adaptability of prosimian species depends on particular aspects of their digestive tracts. The chewing movement was acquired at an early evolutionary stage, according to the shape of the teeth (Kay and Hiiemae, 1974), and there is little possible change in the way food is masticated (see Section 1.2 above). The intestinal tract, on the other hand, may undergo marked changes (Hladik, 1967) as an adaptation to dietary change, in particular, the less differentiated digestive tract (without large chambers of bacterial fermentation). The general proportions of the digestive tract (Amerasinghe et al., 1971; Chivers and Hladik, in prep.) are correlated with the diet, the insectivorous and frugivorous species having a long small gut, while the extension of the cecum and the hindgut characterizes the species feeding on gums and leaves (Fig. 12). But further physiological and behavioral adaptations, such as cecotrophy, are as important as these morphological characteristics.

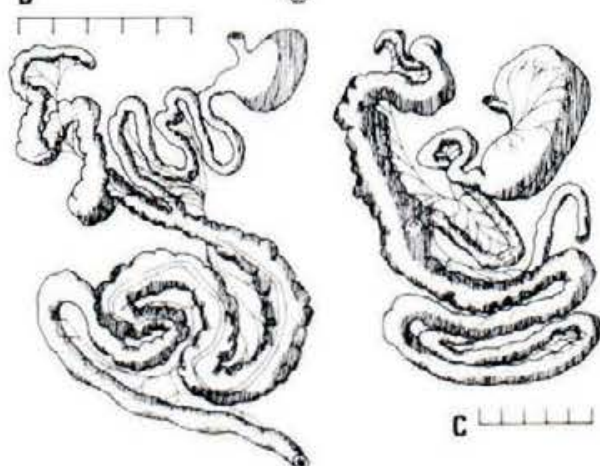

Fig. 12. Proportions of the different parts of the digestive tract of three prosimian species. These drawings were made from samples collected in the wild, partly dissected to show the different sections with special attention paid to accurate dimensions; measurements were taken after complete dissection to verify the lengths indicated in the drawings. The scale for each specimen represents $5 \mathrm{~cm}$. (A) Arctocebus calabarensis. (B) Galago elegantulus. (C) Lepilemur leucopus.

\subsection{Cecotrophy in Lepilemur}

The particular physiological and behavioral mechanism of the digestion of leaves by Lepilemur leucopus has been described by Charles-Dominique and Hladik (1971) and analyzed by Hladik et al. (1971b). Recent observations on Lepilemur ruficaudatus (J. J. Petter, personal communication) reveal a similar behavior, - suggesting that it is a feature common to the different species of the genus Lepilemur.

Lepilemur leucopus, which feed mainly on crassulescent leaves, flowers, and some fruits, reingest a part of the fecal material, just as the rabbit does (Taylor, 1940); but this material is very different from that of the rabbit. The food ingested under natural conditions by $L$. leucopus, during the period of observations, was a mixture of the flowers of two species of Alluaudia (cf. Hladik and CharlesDominique, 1974) which was found to have an average composition of $15.1 \%$ protein, $2.7 \%$ lipids, $5.8 \%$ soluble sugars, $16.7 \%$ cellulose, $9.1 \%$ minerals, the rest of the dry matter being made up of fiber, mainly hemicellulose and lignin. Very 
little hemicellulose is hydrolyzed in the stomach and the small gut after the animal starts feeding at night. Part of the cellulose is hydrolyzed in the cecum. The hemicelluloses are slowly hydrolyzed afterward and absorbed in the colon. A portion of the food, partly decomposed in the cecum, passes quickly and is eaten by the animal, licking its anus at intervals during the daytime. This particular food contains a larger proportion of protein than the original food $(45.8 \%)$, as well as a large proportion of hemicelluloses. The soluble components resulting from the bacterial fermentation are absorbed during this second cycle. This unique physiological strategy allows $L$. leucopus to make maximum use of what is ordinarily a very poo diet, in terms of the energy that can be obtained from the soluble components. In fact, it has the poorest diet known among primates with little variation in the food available in two different habitats (Fig. 13).

The extreme shortness of the small gut of $L$. leucopus would not allow sufficient absorption of the soluble components in one direct passage only. According to the histological structure of the cecum (Hladik et al., 1971b) it is likely that a complementary absorption occurs in this part.

The digestive tract of Galago elegantulus resembles that of Lepilemur leucopus and has a similar function of bacterial fermentation of highly polymerized carbohydrates (gums are compounds of pentoses) (Fig. 12). One would, therefore, expect
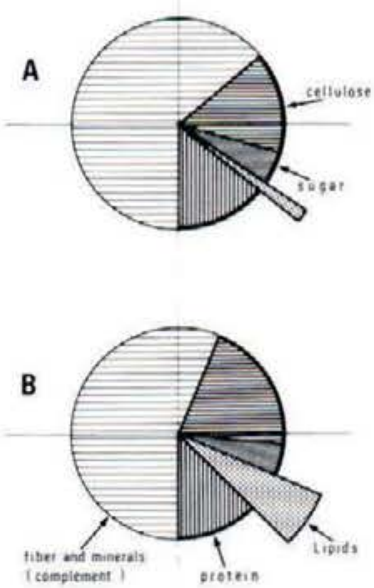

Fig. 13. Proportions of nutrients in the diet of Lepilemur leucopus in two different habitats in the south of Madagascar during the dry season. The larger amount of lipids is proportional to its higher calorific value. (After Hladik and Charles-Dominique. 1974.) (A) In the Didiereacae bush. (B) In the gallery forest. similar behavior (cecotrophy) in both species. However, one G. elegantulus, closely observed for 36 consecutive hours in captivity in Gabon, and fed with gums eaten in the wild, showed no signs of cecotrophy. Among the primates this particular behavior appears to be strictly limited to Lepilemur.

\subsection{Artificial Diets: the G3 Lemur Cake of Brunoy}

A general problem of primate care in captivity is to maintain a minimum standard of diet (Wackernagel, 1966, 1968). This has been done successfully in several zoos, for example, in Basel, where species of leaf monkey, reputed to be unable to adapt to captive conditions, are kept in excellent health. Success is partly due to the introduction of raw grasses, improperly called "monkey cake," containing minerals and vitamins to offset any deficiency in the diet.

At the animal house in Brunoy, different types of dietary supplements have been tested. The "monkey cake" was rejected by the small species of prosimian. A composition, more refined in texture, made of cooked semolina, was finally accepted. The composition of this cake was based on the natural foods of the smallest species of Callithricidae (Hladik et al., 197la) because no data on the natural food of prosimians were available at that time.

The G3 lemur cake (third formula worked out by Mrs. Grange) includes large amounts of proteins and lipids (Tables IV and V) and is accepted, sometimes after a few days, by all the prosimian species presently at Brunoy. It is given only in small quantities, as a supplementary and not as a substitute diet, and has been found to be very efficient in maintaining a good rate of reproduction in some species considered

TABLE IV

Recipe for the G3 Lemur Cake"

In a 12-liter stew pan. pour successively:

5 liters of water (heat)

$2 \mathrm{~kg}$ of semolina (slowly mixed in the water)

$1 \mathrm{~kg}$ of white cheese, $40 \%$ fat

$1 \mathrm{~kg}$ of white cheese without fat

$250 \mathrm{gm}$ of butter (slowly stir the hot mixture, but stop heating)

36 eggs (about $1800 \mathrm{gm}$ )

One tin of sweetened concentrated milk ( $397 \mathrm{gm}$ )

$10 \mathrm{gm}$ of salt

$100 \mathrm{gm}$ of pure fructose

$300 \mathrm{gm}$ of pure glucose (continue stirring until the mixture is cool)

The mixture is transferred in 25 plastic boxes containing about $500 \mathrm{gm}$ each. then add:

5 drops of "Vitapaulia" (Proligo-78800 Houilles, France) in each of the boxes when the mixture is cold but not yet hardened

a $12 \mathrm{~kg}$ fresh weight which can be stored in a freezer. 
TABLE V

Composition of the G3 Lemur Cake

Water: $64.9 \%$ of the frem weigh

Percentage of the dry weight:

Carbohydrate 54.1

Protein 22.2

Lipids 22.1

Minerals $\quad 1.53 \quad$ (including calcium 0.38 and phosphorus 0.404

"delicate" in captive conditions, such as Lepilemur ruficaudatus and Microcebus coquereli, for which the available natural food would have been insufficient.

\section{FOOD COMPOSITION AND FEEDING BEHAVIOR OF} PROSIMIANS

\subsection{Regulation of Feeding Behavior}

The role of the hypothalamic nuclei in the regulation of hunger and satiety has been demonstrated in many mammalian species including primates. Taste stimulation also plays an important role (Le Magnen, 1966: Aschkenasy-Lelu, 1966) in parallel with this system of regulating food intake according to the demands of the "milieu interne."

The long-term effects of food intake on the state of the "milieu interne" of the animal could originate by a process of conditioning, positive in the case of correct types of food resulting in beneficial effects, and negative in the case of noxious substances, unbalanced or inadequate diets, resulting in illness. Nevertheless, positive conditioning by taste stimulation is likely to be involved in most cases and can explain many differences in the particular feeding behavior of the different prosimian species.

\subsection{Food Conditioning under Natural Conditions}

The long-term beneficial effect is obviously the major criterion determining diet in the Lorisinae, since they feed on insects rejected by other prosimians because of their taste, but their preferential choice of more palatable prey, when available (see Section 1.2 above), shows that the immediate response to pleasurable taste stimulation is not absent in determining food choices

Conditioning as a result of the immediate effect of taste stimulation might be very important in natural conditions, in increasing the efficiency of a species having a grade 2 diet, as well as those having a grade 1 diet, which includes large amounts of fruits. These species generally have a large supplying area in which scattered food resources must first be located. Vision is the predominant sense involved in food detection, as shown by Pariente (Chapter 10), the moving prey and the stationary prey providing different kinds of stimulation. (Hearing also plays a role in some of these cases; see Sections 2.3.6 and 2.4.6). Color vision, though imperfect, is very important in diurnal species for increasing the contrast of certain fruits against the green background of foliage. Whatever the case, interest in a particular kind of food may

- be increased by taste stimulation of such soluble substances as sugars and organic acids, which may constitute a reward in itself and induce positive conditioning.

Prosimian species which have grade 3 diets (exclusively utilizing the primary production) are probably conditioned to dietary preferences by their long-term effects. This is apparent for example, in operant conditioning tests on Hapalemur griseus: a reward of a piece of cucumber, even though it represents only a small return in energy, may be preferred to higher energy foods such as sweet fruits and insects $(H$. Cooper, personal communication). Nevertheless, among the species feeding on fruits and leaves, the role of taste can explain differences in feeding strategy, particularly between the sympatric Lemur species, L. fulvus and L. catta (Section 2.5.2). This example, as well as other cases of sympatry between Lemur and/or Propithecus species, needs more investigation into the composition of preferred plant species. The parallel example of sympatric simian species utilizing the same type of habitat in Sri Lanka (Hladik. 1977a) shows that interspecific differences in food preference cannot be due exclusively to the long-term effects. It can be predicted that interspecific differences in taste perception (or in taste stimulation) of the same substances will be found. The evolution of these different sensory characteristics (some of them already demonstrated in simian primates by Glaser and Hellekant, 1977) could have resulted in different feeding strategies: some species with greater taste sensitivity specializing in scattered and rich resources, while others with less sensitive tastes developed long-term preferences for the more - common food resources.

\section{DISCUSSION AND CONCLUSIONS}

The primary factors which condition prosimian species to the various dietary grades are the beneficial effects of the nutritional constituents.

Many substances in plants, which are not nutritious, may play a role, generally a nociceptive one, in the physiological and sensory reaction of the animal which feeds on them. These substances, described as "secondary compounds" or "allelochemics" by Whittaker and Feeny (1971), may act either to repel or attract insects. The same type of substance is also found in the invertebrates. The glandular secretions of different insects may be one of these secondary compounds taken from a plant on which the insect feeds and which it then concentrates or otherwise 
chemically modifies in some way. For some prosimian species, feeding on these insects, the "repellent" substance actually functions as an attractant.

Secondary substances found in many plant species, such as alkaloids, tannins. saponins, glucosides, may play a similar double role in the orientation of feeding behavior of different prosimian species. In fact, very little is known of the composition of the plant species used as food by prosimian species, and most of these suggested effects of the so-called "secondary" substances are speculative.

In the data collected on simian food (C. M. Hladik, 1977a, b, 1978; A. Hladik, 1978), there are very few examples of strong concentrations of toxic or noxious substances in fruits and/or leaves which would lead to avoidance responses. In most cases the concentrations are very low and secondary substances do not play a nociceptive role. Many types of food eaten by simians are also eaten by prosimians and their effect is probably similar, except that, as has been noted, some species are actually attracted to certain foods because of taste and/or smell which repels other species. Several plant species have selected fruit attractants as a mechanism for seed dispersion and other vital functions (Levina, 1957; Hladik and Hladik, 1967).

Efficient conditioning to a particular diet, due to its long-term beneficial effects, is further reinforced by the smell and taste of these secondary compounds. Thus the presence of these substances must be very helpful in maintaining the feeding strategies of prosimian species, with grade 2 or 3 diets, which use scattered resources in a large supplying area.

Eating earth (geophagy), observed by Pollock (1975) in Indri indri (see Section 2.5.5), may represent a very different feeding strategy. It has been shown, for instance, that for many folivorous primate species, which eat some earth, the required concentration of the mineral nutrients is lower in the earth than in many leaves used as a food (Hladik and Guegen, 1974). A possible function of earth eating could be that earth serves to adsorb those tannins or other secondary substances that are in excess in certain types of food.

It is confidently expected that, in a few years, our knowledge of the composition of the food used by prosimians will lead to verification of the above hypotheses. Further research work on feeding behavior must be complemented by laboratory tests on conditioning to determine the taste thresholds of different prosimian species for various nutrients and secondary compounds, and to define the basis of the behavioral adaptations to various food resources in different habitats.

\section{ACKNOWLEDGMENTS}

Many ideas expressed in this chapter were developed and discussed at Brunoy while J.-J. Petter. A Petter-Rousseaux. P. Charles-Dominique, G. Pariente, A. Schilling, A. Hladik, E. Pagès, M. Perret. and $\mathrm{H}$. Cooper were doing research or returning from field trips. Special thanks are also due to the editors, G. A. Doyle and R. D. Martin, for their active and patient cooperation.

\section{REFERENCES}

Amerashinghe, F. P., Van Cuylenberg, B. W. B., and Hladik, C. M. (1971). Ceylon I. Sci., Biol. Sci 9. $75-87$.

Andriantsiferana, R., and Rahandraha. T. (1973). C. R. Hebd. Séances Acad. Sci. 277, 2025-2028 Aschkenasy-Lelu, P. (1966). J. Sci. Cent. Natl. Coord. Etud. Aliment. 14, 55-101.

Bearder, S. K., and Doyle, G. A. (1974), In "Prosimian Biology" (R. D. Martin, G. A. Doyle, and A C. Walker, eds.), pp. 109-130. Duckworth. London.

Bishop, A. (1964). In "Evolutionary and Genetic Biology of Primates" (J. Buettner-Janusch. ed.), Vol 2. pp. 133-225. Academic Press, New York.

Bourlière, F. (1974). In “Prosimian Biology“ (R. D. Martin, G. A. Doyle, and A. C. Walker, eds.), pp 17-22. Duckworth, London.

Budnitz, N., and Dainis, K. (1975). In "Lemur Biology" (I. Tattersall and R. W. Sussman, eds.), pp. 219-235. Plenum Press. New York.

Buettner-Janusch, J, and Andrew, R. J, (1962). Am. J. Phys. Anthropol, 20, 127-129.

Charles-Dominique, P. (1966). Biol, Gabonica 2, 347-353.

Charles-Dominique, P. (1971a). Biol. Gabonica 7, 121-228

Charles-Dominique, P. (1971b). Recherche 15, 780-781.

Charles-Dominique, P. (1972). Z. Tierpsychol. . Beih. 9, 7-41

Charles-Dominique, P. (1974a). In "Prosimian Biology" (R. D. Martin. G. A. Doyle, and A. C Walker, eds.), pp. 131-150. Duckworth. London.

Charles-Dominique, P. (1974b). Mammalia 38, 355-379.

Charles-Dominique, P. (1974c). In "Primate Aggression. Territoriality and Xenophobia: A Comparative Perspective" (R. L. Holloway, ed.), pp. 31-48. Academic Press, New York.

Charles-Dominique, P. (1975), In "Phylogeny of the Primates: A Multidisciplinary Approach" (W. P. Luckett and F. S. Szalay, eds.), pp. 69-88. Plenum, New York.

Charles-Dominique, P. (1976). Oiseau Rev. Fr. Ornithol, 46, 174-178

Charles-Dominique, P. (1977a), “Ecology and Behaviour of Nocturnal Primates." Duckworth, London. Charles-Dominique, P. (1977b). Z. Tierpsychol, 43, 113-138.

Charles-Dominique, P. (1978). In "Recent Advances in Primatology." Vol. 3: Evolution (D. J. Chivers and K. A. Joysey, eds.), pp. 139-149. Academic Press, London.

Charles-Dominique, P., and Hladik, C. M. (1971). Terre Vie 25, 3-66.

Charles-Dominique, P., and Martin, R. D. (1970). Nature (London) 227, 257-260.

Charles-Dominique, P. and Petter. J. J. (in press). In "Ecology, Physiology, and behavior of five nocrurnal lemurs of the west coast of Madagascar" (P. Charles-Dominique, ed.), Karger, Basel

Cooper, H. (1978), In "Recent Advances in Primatology. Vol. I: Behaviour" (D. J. Chivers and J. Herbert, eds.). pp. 941-944. Academic Press, London.

Doyle, G. A. (1974a). Behav. Nonhum. Primates 5, 155-353

Doyle, G. A. (1974b), In "Prosimian Biology" (R. D. Martin. G. A. Doyle, and A. C. Walker, eds.), pp, 213-231. Duckworth, London.

Doyle, G. A. and Martin, R. D. (1974). In "Prosimian Biology" (R. D. Martin, G. A. Doyle, and A. C. Walker, eds.), pp. 3-14. Duckworth, London.

Elliot. O., and Elliot. M. (1967). J. Mammal. 48, 497-498.

Fogden. M. P. L. (1974). In "Prosimian Biology" (R. D. Martin, G. A. Doyle, and A. C. Walker, eds.), pp. 151-165. Duckworth. London.

Garcia, J., Hankins, W. G.. and Rusiniak. K. W. (1974). Science, 185. 824-831.

Gautier-Hion, A. (1971), Terre Vie 25, 427-490.

Glaser. D and Hellekant, G (1977). Folia primatol, 28, 43-51.

Hill, W. C. O (1953) "Primates: Comparative Anatomy and Taxonomy," Vol. 1. Edinburgh Univ. Press. Edinburgh. 
Hill, W. C. O. (1955), “Primates: Comparative Anatomy and Taxonomy," Vol. II. Edinburgh Univ Press, Edinburgh.

Hinde, R. A. (1966). “Animal Behaviour: A Synthesis of Ethology and Comparative Psychology," McGraw-Hill, New York.

Hladik, A. (1978). In "The Ecology of Arboreal Folivores" (G. G. Montgomery, ed.), in press Random House Smithsonian Inst. Press, New York.

Hladik, A., and Hladik, C. M. (1969). Terre Vie 23, 25-117.

Hladik. C. M. (1967), Mammalia 31, 120-147.

Hladik. C. M. (1973), Terre Vie 27, 343-413.

Hladik, C. M. (1975). In "Socioecology and Psychology of Primates" (R. H. Tuttle, ed.), pp. 3-35 Mouton, The Hague.

Hladik, C. M. (1977a), In "Primate Ecology: Studies of Feeding and Ranging Behaviour in Lemurs, Monkeys and Apes" (T. H. Clutton-Brock, ed,), pp. 323-353. Academic Press, New York.

Hladik, C. M. (1977b). In "Primate Ecology: Studies of Feeding and Ranging Behaviour in Lemurs, Monkeys and Apes" (T. H. Clutton-Brock, ed.). pp. 595-601. Academic Press, New York.

Hladik, C. M. (1978). In "The Ecology of Arboreal Folivores" (G. G. Montgomery, ed.), in press Random House, Smithsonian Inst. Press, New York.

Hladik, C. M. and Charles-Dominique, P. (1974). In "Prosimian Biology" (R. D. Martin, G. A. Doyle, and A. C. Walker, eds.), pp. 23-37. Duckworth, London.

Hladik, C. M and Chivers, D. J. (1978), In "Recent Advances in Primatology, Vol. 1: Behaviour" (D. J. Chivers and J. Herbert, eds.), pp. 433-444. Academic Press, London,

Hladik, C. M., and Guegen, L. (1974). C. R. Hebd. Séances Acad. Sci. 279, 1393-1396.

Hladik, C. M., and Hladik, A. (1967). Biol. Gabonica 3, 43-58.

Hladik. C. M., and Hladik, A. (1972), Terre Vie 26, 149-215.

Hladik, C. M., Hladik, A., Bousset, J., Valdebouze, P., Viroben, G., and Delort-Laval, J. (1971a). Folia Primatol. 16, 85-122.

Hladik, C. M., Charles-Dominique, P. Valdebouze, P. Delort-Laval, J., and Flanzy, J, (1971b), C. R. Hehd. Séances Acad. Sci. 272, 3191-3194.

Hladik, C. M., Charles-Dominique, P., and Petter, J. J. (in press). In "Ecology, physiology and behaviour of five nocturnal lemurs of the west coast of Madagascar " (P. Charles-Dominique, ed.), Karger, Basel.

Hutchinson, G. E. (1957). Cold Spring Harbor Symposia on quantitative Biology, 22, 415-427.

Iwamoto. T. (1974a), Primates 15, 241-262.

Iwamoto, T. (1974b). In "Contemporary Primatology" (S. Kondo, M. Kawai, and E. Ehara, eds.), pp. 475-480. Karger, Basel.

Jameson, E. W., and Mead. R. A. (1964). J. Mammal. 45, 359-365

Jolly, A. (1966). "Lemur Behavior: A Madagascar Field Study." Univ. of Chicago Press, Chicago, Illinois.

Kay, R. F., and Hiiemac, K. M. (1974). In "Prosimian Biology" (R. D. Martin. G. A. Doyle, and A. C. Walker, eds.). pp. 501-530. Duckworth. London.

Kay, R. F., and Hylander, W. (1978). In "The Ecology of Arboreal Folivores" (G. G. Montgomery, ed.), in press. Random House (Smithsonian Inst. Press), New York.

King, G. (1974). Jersey Wildl. Preserv. Trust: Ann. Rep. pp. 81-96.

Le Magnen, J. (1966). J. Sci. Cent. Natl. Coord. Etud. Aliment. 14, 1-54

Levina, R. E. (1957). "Dispersal of Fruits and Seeds." Univ. of Moscow Press, Moscow (in Russian)

Martin. R. D. (1972a). Z. Tierpsychol. Beih. 9, 43-89.

Martin, R. D. (1972b) Philos. Trans. R. Soc, London, Ser. B 264. 295-352.

Martin, R. D. (1973). In "Comparative Ecology and Behavior of Primates" (R. P. Michael and J. H Crook, eds.), pp. 1-68. Academic Press, New York.

Napier, J. R., and Walker, A. C. (1967). Folia Primatol. 6, 204-219.

Odum. E. P.. and Odum. H. T. (1959). "Fundamentals of Ecology." Saunders, Philadelphia, Pennsylvania.
Pagès, E (1978), In "Recent Advances in Primatology, Vol. 3: Evolution" (D. J. Chivers and K. A Joysey, eds.), pp. 171-177. Academic Press, London.

Pariente. G. (1975). J. Physiol. (Paris) 70. 637-647.

Pariente, G. (1976). Doctoral Thesis, Université des Sciences et Techniques du Languedoc (unpublished). Montpellier (France).

Perret. M. (1972). Mammalia 36, 482-516.

Perret, M. (1974). In "Prosimian Biology" (R. D. Martin, G. A. Doyle, and A. C. Walker, eds.), pp, 357-387. Duckworth, London.

Petter, J. J. (1962). Mém. Mus. Natn. Hist. Nat. Paris Sér. A 27, 1-146.

d Petter. J. J. (1978). In "Recent Advances in Primatology, Vol. 1: Behaviour (D. J. Chivers and J. Herbert, eds.), pp. 211-223. Academic Press, London.

4 Petter, J. J., and Hladik, C. M. (1970). Mammalia 34, 394-409

- Petter, J. J., and Petter-Rousseaux, A. (1967). In "Social Communication among Primates" (S. A Altmann, ed.), pp. 195-205. Univ. of Chicago Press, Chicago, Illinois.

Petter, J. J.. and Peyrieras, A. (1970a). Mammalia 34, 167-193.

Petter. J. J., and Peyrieras, A. (1970b). Terre Vie 24, 356-382.

Petter, J. J., and Peyrieras, A. (1974). In "Prosimian Biology" (R. D. Martin, G. A. Doyle, and A. C. Walker, eds.), pp. 39-48. Duckworth, London.

Petter. J. J. and Peyrieras, A. (1975). In "Lemur Biology" (I. Tattersall and R. W. Sussman, eds.), pp. 281-286. Plenum, New York.

Petter, J. J.. Schilling. A.. and Pariente, G. (1971), Terre Vie 25, 287-327.

Petter, J. J., Albignac, R., and Rumpler, Y. (1977). "Faune de Madagascar: Lémuriens. " ORSTOM CNRS, Paris.

Petter-Rousseaux, A. (1974). In “Prosimian Biology" (R. D. Martin, G. A. Doyle, and A. C. Walker. eds.), pp. 365-373. Duckworth, London.

Petter-Rousseaux, A. and Hladik. C. M. (in press). In "Ecology, physiology, and behavior of five nocturnal lemurs of the west coast of Madagascar." (P. Charles-Dominique. ed.). Karger. Basel. Philips, W. W. A. (1931) Cevlon J.Sci, 16, 205-208

Pollock, J. (1975). Ph.D. Thesis, University of London (unpublished).

Pollock, J. (1977). In "Primate Ecology: Studies of Feeding and Ranging Behaviour in Lemurs, Monkeys and Apes" (T. H. Clutton-Brock, ed.), pp. 37-69. Academic Press, New York.

Richard, A. F. (1973). Ph.D. Thesis, University of London (unpublished).

Richard. A. F. (1974). Folia Primatol. 22, 178-207.

Sauer, E. G. F., and Sauer. E. M. (1963). J. S.W. Afr. Sci. Soc. 16, 5-36.

Still, J. (1905). Spolia Zeylan. 3, 155 .

- Sussman. R. W. (1972). Ph.D. Thesis, Duke University, Durham, North Carolina (unpublished). Sussman, R. W. (1974). In "Prosimian Biology" (R. D. Martin, G. A. Doyle, and A. C. Walker, eds.) pp. 75-108. Duckworth, London.

7 Sussman, R. W., and Richard. R. F. (1974). In "Primate Aggression. Territoriality and Xenophobia: A Comparative Perspective" (R. L. Holloway, ed.). pp. 49-75. Academic Press, New York.

Taylor, E. L. (1940), Vet. Rec. 52, 259-262.

Thorington, R. W. (1967). In “Progress in Primatology“ (D. Starck, R. Schneider, and H. J. Kuhn. eds.). pp. 180-184. Fischer, Stuttgart.

Wackernagel, H. (1966). Int. Zoo Yearb. 6, 23-37,

Wackemagel, H. (1968). Symp. Zool. Soc. London 21, 1-12.

Walker, A. C. (1969). Uganda I. 32, 90-91.

Whittaker, R. H., and Feeny, P. P. (1971), Science 171, 757-770. 